\title{
사회경제적 지위가 면접에서의 인상관리 책략에 미치는 영향: 통제감의 매개효과*
}

\author{
$\begin{array}{crrrr}\text { 김 영 도 장 재 윤 } & \text { 남 상 희 } \\ \text { 서강대학교 심리학과 } & & \text { 충북대학교 심리학과 }\end{array}$
}

본 연구의 목적은 사회경제적 지위(socio-economic status)가 채용장면에서 정직한 인상관리 책략(honest impression management tactics) 및 기만적 인상관리 책략(deceptive impression management tactics) 사용에 미치는 영향을 확인하고, 이 관계를 통제감(sense of control)이 매개하는지 살펴보는 것이다. 채용면접 경험이 있는 대학생 235명을 대상으로 정직한 인상관리에서는 자기홍보(self-promotion), 정직한 환심사기(honest ingratiation), 정직한 방어(honest defensive impression management)의, 기만적 인상관리에서는 가벼운 이미지 창 조(slight image creation), 포괄적 이미지 창조(extensive image creation), 기만적 환심사기(deceptive ingratiation), 이미지 보호(image protection)의 총 7가지 책략에 대해 설문조사를 실시한 결과, 주관적 사회경제적 지위 (subjective socio-economic status)는 정직한 인상관리 책략 중 자기홍보 및 정직한 방어를 정적으로 예측하였 으며, 이 관계를 통제감이 매개하였다. 하지만 주관적 사회경제적 지위는 정직한 환심사기 및 기만적 인 상관리 책략과는 유의한 관계를 보이지 않았다. 객관적 사회경제적 지위(objective socio-economic status)가 높 을수록 통제감이 높았으나, 정직한 인상관리 책략 및 기만적 인상관리 책략 중 어떤 것과도 유의한 관련 을 가지지 않았다. 본 연구는 사회경제적 지위에 따라 구직자들의 행동에 차이가 나타난다는 것을 보여줌 으로써, 채용장면에서 사회경제적 지위를 고려할 필요성을 보여주었다는 측면에서 의의가 있으며, 그 기 제로 통제감의 역할을 밝힘으로써 사회경제적 지위의 효과를 설명할 수 있는 기초 자료를 제공하였다는 점에서 의의가 있다.

주요어 : 사회경제적 지위, 채용면접, 정직한 인상관리 책략, 기만적 인상관리 책략, 통제감

* 이 논문은 김영도의 2019년 석사학위 논문을 수정 및 보완하여 정리한 것임.

† 교신저자 : 남상희, 충북대학교 심리학과, 충청북도 청주시 서원구 충대로1, E-mail: baskya@naver.com 
사회계층 간 소득 격차와 ‘부의 불평등' 문 제가 대두되면서, 사회경제적 지위(이하 SES: Socio-Economic Status)에 따른 차이에 주목하는 학자들이 증가하고 있다(예: Amis et al., 2020). Piketty(2014)는 자본을 소유한 상위계층과 상 대적으로 소득의 많은 부분을 노동에 의존하 는 하위계층의 소득 격차가 점차 심각해질 것으로 보았다. 모든 경제학자들이 그의 주장 에 동의하는 것은 아니지만(예: Kuznets, 1955; Mankiw, 2015), 적어도 지금까지는 소득 불평 등이 전세계적으로 심화되는 추세이다(Elliott, 2015; OECD, 2016). 이러한 추세가 반영되어 경제학뿐만 아니라 의학(예: Singh et al., 2017), 역학(예: Dowd et al., 2009), 사회학(예: Nazroo, 1998), 심리학(예: Kraus et al., 2009) 등 많은 분야에서 SES에 주목하고 있다. 이들 연구에 따르면, SES는 신체질환은 물론 정신건강에 이르기까지 광범위한 영향을 미치며(Adler, \& Ostrove, 1999; McLaren, 2007), 상이한 성향체계 가 체화되게 만들고(Bourdieu, 1984), 귀인양식, 자아정체성 등의 인지적 측면에 영향을 준다 (Kraus et al., 2009; Na et al., 2018).

조직 장면에서도 SES 또는 사회계층(social class)에 대한 관심이 증가하고 있다. 예를 들 어, 최근 Ingram(2021)은 조직 다양성(diversity) 논의 과정에서 사회계층을 고려해야 한다고 주장하였다. 그에 따르면, 조직 장면에서 하 위계층 출신 사람들은 문화자본의 부족으로 인한 불이익을 경험하기 때문에, 잠재력을 계 발하고 발휘할 수 있는 기회를 잃게 된다. 이 렇게 하위계층 사람들이 경험하는 불이익은 조직의 관행으로 인해 유지 - 강화될 수 있다 (Amis et al., 2020). Amis 등(2020)은 채용(hiring), 역할할당(role allocation), 승진(promotion), 보상 (compensation) 및 구조화(structuring)의 다섯 가
지 조직 관행들을 통해 경제적 불평등이 유지 및 재생산된다고 하였다. 조직 관행에 의해 하위계층 사람들이 불이익을 겪는 한편, 사 회계층이 높은 구직자들이 더 효과적인 구직 전략을 채택한다는 연구 결과도 있다. 예를 들어, Fang과 Saks(2020)는 SES가 구직강도와 구직성공의 관계를 강화하며, 이것은 사회계 층이 높은 구직자들이 무계획적인 구직전략 (haphazard job search strategy)을 덜 사용하기 때 문이라고 하였다. 이처럼 SES에서의 차이는 구 직 행동에서의 차이를 야기하고, 이는 상대적 으로 낮은 계층의 구직자들이 취업에 어려움 을 겪는 한 원인이 될 수 있다. 이들의 연구 는 조직이 채용과정에서 차별을 최소화하기 위해 노력하더라도 계층에 따른 구직자의 행 동에서의 차이 때문에 하위계층이 비의도적으 로 배제될 수 있음을 보여주었다는 측면에서 주목할 만하다. 더 나아가 조직은 이러한 비 의도적인 배제로 유능한 직원을 선발할 기회 를 잃게 된다.

본 연구에서는 채용장면에서 SES가 구직자 들의 행동에 미치는 영향을 탐구하고자 하였 으며, 채용과정의 필수적인 절차인 면접상황 에 주목하였다. 오늘날 기업의 채용장면에서 가장 널리 사용되는 방법은 면접이다(Huffcutt \& Culbertson, 2011). 한국경영자총협회가 실시 한 '2017 신입사원 채용 실태조사'에서도 300 인 이상 규모의 기업 312 곳 중에서 면접을 선 발방식으로 채택한 기업이 $98 \%$ 로서, 다른 선 발방식에 비해 가장 높은 비율이었다. 면접의 다양한 형태 중 인성 면접은 직무역량 면접과 더불어 가장 자주 사용되는 방식으로서, 동 일조사에서 대기업은 $85 \%$ 이상이 인성 면접 을 실시하는 것으로 나타났다(Korea Employers Federation, 2017). 직무 경험이나 학점과 같은 
객관적인 지표들이 면접단계까지의 도달 여 부를 결정하지만, 최종 합격을 결정하는 것 은 대부분 면접장면에서의 수행이다(Dipboye, 1992). 만약 SES에 따라 면접장면에서의 행동 이 달라질 수 있다면, 그로 인해 면접결과 및 채용 여부에도 영향을 미칠 것이다. 따라서, $\mathrm{SES}$ 와 면접에서의 행동 간의 관계를 살펴볼 필요가 있다.

면접 내 행동에 대한 SES의 효과를 확인하 는 것의 중요성에도 불구하고, 관련 연구는 부족한 실정이다. 가령 Fang과 Saks(2020)는 직 무면접(job interview)과 직무제안(job offer) 간 관 계가 부모의 소득이 높을 때 강화된다는 것을 보여주었지만, 그 기제에 대해서는 자세히 밝 히지 못하였다. 다만, 여러 선행연구들은 SES 가 면접 과정에서 구직자들의 인상관리 책략 (이하 IM: Impression Management tactics)에 영 향을 미칠 수 있음을 시사한다(예: Belmi \& Laurin, 2016; Piff et al., 2010; Stephens et al., 2014; Stern \& Westphal, 2010). 예를 들어, SES 가 높은 사람들은 더 자신감이 있으며, 눈에 띄고자 하고 독특함을 유지하려는 경향이 있 고(Stephens et al., 2014), 정교한(sophisticated) IM 을 더 많이 사용한다(Stern \& Westphal, 2010). 반면, 상대적으로 SES가 낮은 사람들은 정치적 인 행동이나 과도한 자기홍보(self-promotion)를 주저하는 경향이 있다(Belmi \& Laurin, 2016).

$\mathrm{IM}$ 은 자신에 대한 인상에 영향을 미치기 위해 사용하는 자기 제시 행동으로서(Leary \& Kowalski, 1990), 다양한 사회적 상황 속에 서 발생하지만 채용면접과 같은 고부담(high stakes) 맥락에서 특히 더 자주 나타난다 (Bourdage et al., 2018; Rosenfeld, 1997). 구직자 에게 최근의 면접에 대해 질문하였을 때, $81 \%$ 가 적어도 하나 이상의 거짓말을 하였다고 응
답하였으며(Weiss \& Feldman, 2006), 정직하게 자신을 제시하는 $\mathrm{IM}$ 은 거의 모든 구직자들 (99\%)이 사용하였다고 응답하였다(Bourdage et al., 2018, Study 3). 또한, 면접 맥락에서 IM의 사용은 면접결과에도 영향을 미칠 수 있다 (Kacmar \& Carlson, 1999; Kristof-Brown et al., 2002). 가령, Peck과 Levashina(2017)는 메타분석 을 통해 다양한 형태의 IM 사용과 면접평가 간 정적인 관계를 확인하였다. 만약 SES에 따 라 $\mathrm{IM}$ 의 사용이 달라진다면 이것은 결과적으 로 SES에 따른 구직 성과의 차이를 야기할 수 있을 것이다.

이상의 문제의식을 바탕으로 본 연구에서는 SES가 면접장면에서 구직자의 IM 사용에 어떠 한 영향을 미치는지를 살펴보고자 하였다. 일 반적으로 SES가 낮은 사람들은 자기효능감이 낮고, 운명이나 권력자의 역할을 높게 평가 하는 등 낮은 통제감(sense of control)을 갖는 경향이 있으며(Gurin \& Brim, 1984; Lachman, 1985), 면접장면에서 통제감의 수준에 따라 어떤 IM을 사용할지에 영향을 미칠 수 있다 (Delery \& Kacmar, 1998). 따라서 본 연구는 다 음과 같은 목적을 가지고 진행되었다. 첫째, 면접장면에서 SES에 따른 구직자들의 IM 사용 에서의 차이를 밝히고자 하였다. 둘째, SES가 $\mathrm{IM}$ 사용에 영향을 미치는 기제로서 통제감에 주목하여 SES와 IM 사용 간의 관계에 대한 통 제감의 매개효과를 탐구하였다. 이를 위해 본 연구에서는 인성 면접 경험이 있는 대학생들 을 대상으로 온-오프라인 설문을 진행하여 $\mathrm{SES}$ 와 인성 면접에서의 IM 사용 간 관계를 확 인하였다. 


\section{인상관리(IM)}

$\mathrm{IM}$ 은 사회적 상호작용 과정에서 본인 성격 의 특정 측면에 대한 다른 사람들의 인상을 통제하려는 시도로서(Leary \& Kowalski, 1990; Peck \& Levashina, 2017; Schlenker, 1980), 면접장 면에서는 면접관들의 마음에 특정한 이미지를 만들어내려는 지원자들의 노력이라고 할 수 있다(Roulin et al., 2015). 거의 모든 지원자들 은 면접장면에서 IM을 사용하지만(Levashina \& Campion, 2007; Turnley \& Bolino, 2001), 그 방 식은 다르다.

면접에서의 $\mathrm{IM}$ 을 구분하는 방식은 연구자 마다 상이하지만(예: Roulin et al., 2015; Van Iddekinge et al., 2007), Table 1에서 볼 수 있듯 이 크게 적극적(assertive) IM과 방어적(defensive) IM으로 구분할 수 있다(Bourdage et al., 2018; Tsai et al., 2010). 적극적 IM은 지원자가 특정 한 관점, 가치, 지식, 특질, 경험 등을 지녔음 을 드러내어 긍정적인 이미지를 얻기 위한 책 략이며(Tedeschi \& Melburg, 1984), 지원자 본인 이 가진 능력과 경험을 강조하는 경우에는 자 기초점 IM으로, 반대로 지원자 본인이 아닌 면접관이 지닌 가치와 의견에 동조하는 경우 타인초점 IM으로 나뉜다(Roulin et al., 2014). 그리고 방어적 $\mathrm{IM}$ 은 변명이나 정당화와 같이 자신의 이미지가 손상되지 않도록 보호하거나 이미지를 회복하기 위한 책략이라고 할 수 있
다(Tsai et al., 2010).

적극적 $\mathrm{IM}$ 과 방어적 $\mathrm{IM}$ 은 다시 정직한 (honest) IM과 기만적(deceptive) IM으로 나눌 수 있다(Levashina \& Campion, 2007; Levashina et al., 2014; Rosenfeld, 1997; Roulin et al., 2014). 정직 한 $\mathrm{IM}$ 은 상대방에게 자신이 직무요건에 적합 한 능력 및 자질을 보유하였음을 보여주기 위 해 직무와 관련된 실제 능력, 성과, 경험 등을 전달하는 책략이다. 이에 반해 기만적 $\mathrm{IM}$ 은 직무와 관련된 자격이나 자질 등을 거짓으로 꾸미거나 지어낸다는 점에서 다르다(Roulin et al., 2014). 최근 Bourdage 등(2018)은 정직한 IM 척도를 개발하여, Levashina와 Campion(2007)의 기만적 IM 측정 도구와 통합하여 제시하였다. 그들의 척도에 의하면 정직한 $\mathrm{IM}$ 에는 적극 적 책략으로서 자기홍보(self-promotion)와 정 직한 환심사기(honest ingratiation), 방어적 책 략으로서 사과(apologies), 변명(excuses) 및 정 당화(justification)가 있으며, 기만적 IM에는 적 극적 책략으로서 가벼운 이미지 창조(slight image creation)와 포괄적 이미지 창조(extensive image creation) 및 기만적 환심사기(deceptive ingratiation), 방어적 책략에는 이미지 보호 (image protection)가 있다.

여러 연구자들이 면접 맥락에서 IM 행동의 선행요인들을 탐색하였다(예: Bourdage et al., 2018; Levashina \& Campion, 2006; Van Iddekinge et al., 2007). 그 중 Levashina와 Campion(2006)은

Table 1. Impression Management Tactics

\begin{tabular}{cccc}
\hline & & honest IM & deceptive IM \\
\hline \multirow{2}{*}{ assertive } & self-focused & self-promotion & slight image creation \\
& & & extensive image creation \\
\cline { 2 - 4 } & other-focused & honest ingratiation & deceptive ingratiation \\
\hline defensive & & apologies, excuses, justification & image protection \\
\hline
\end{tabular}


면접 기만 모델(model of interview faking)에서 $\mathrm{IM}$ 을 능력, 의지, 기회의 함수라고 제안하였 다. 즉, 면접에서의 기만은 1) 면접 수행을 극 대화하는데 필요한 언어적·사회적·인지적 기술과 같은 능력(capacity), 2) 기만적으로 응답 하려는 의지(willingness), 그리고 3) 면접 구조 (예: 구조화의 정도)나 질문형태(예: 과거 행동 질문 대 상황 질문)에 따른 응답 왜곡의 기 회 여부(opportunity)에 달려 있다. Bourdage 등 (2018)은 이 면접 기만 모델을 정직한 IM과 기만적 IM 모두에 적용하여 지원자의 능력, 의지, 기회에 영향을 미칠 수 있는 광범위한 선행요인들을 조사하였고, 정직한 IM과 기만 적 $\mathrm{IM}$ 을 예측하는 선행요인이 다르다는 것 을 발견하였다. 예를 들어, 인구통계적 변인 중 성별과 면접 훈련 경험은 정직한 IM과, HEXACO(Lee \& Ashton, 2004)의 정직-겸손성 차원은 기만적 $\mathrm{IM}$ 과, 외향성은 정직한 $\mathrm{IM}$ 과 기만적 IM 모두와 관련되어 있었다. 또한 이들은 학점, 경쟁적 세계관(competitive world view), 조직의 매력도, 면접에 대한 의욕 (motivation), 면접 난이도, 절차적 공정성과 같 은 다양한 선행요인의 효과를 살펴보았지만, SES가 면접장면에서 IM 사용에 미치는 영향을 고려하지는 않았다. 또한, Sandal 등(2014)은 10 개국의 대학생들을 대상으로 면접장면에서 역 량(competency) 지향(예: 자신의 탁월성을 강조 하는 것) 또는 관계(relationship) 지향(예: 성실 하고 겸손한 태도를 보이는 것)과 연관된 여 러 자기 제시 책략(self-presentation tactics)들의 사용에 있어 문화 차이를 확인하였다. 이들은 $\mathrm{SES}$, 성별, 연령과 같은 개인적 배경과 자기 제시 책략 간 의미 있는 관계를 발견하지 못 했지만, 이 연구는 정직한 IM과 기만적 $\mathrm{IM}$ 을 구분하지 않았다는 데서 한계가 있다. 정직한
$\mathrm{IM}$ 과 기만적 $\mathrm{IM}$ 을 예측하는 선행요인과 면 접결과와의 관계가 다르다는 점을 고려할 때 (Bourdage et al., 2018), 이 각각의 IM을 구분하 여 SES와의 관계를 살펴볼 필요가 있다.

$\mathrm{IM}$ 을 정직과 기만의 두 가지로 명료하게 구분한 것은 비교적 최근 일이다(Bourdage et al., 2018). 과거 연구들은 정직-기만 차원에 대 한 고려 없이 면접 평가에 대한 자기-타인초 점 $\mathrm{IM}$ (적극적 $\mathrm{IM}$ )의 효과를 비교하였으며 (Kacmar et al., 1992; Kristof-Brown et al., 2002), 대체로 타인초점 책략에 대한 자기초점 책략 의 상대적 우월성을 발견하였다(예외: Higgins \& Judge, 2004). Peck과 Levashina(2017)의 메타분 석 결과에 따르면, 자기 및 타인초점 IM 모두 면접 평가를 정적으로 예측하였으며, 대체로 자기초점 $\mathrm{IM}$ 은 타인초점 $\mathrm{IM}$ 보다 면접 평가와 더 높은 상관관계를 보였다. 방어적 $\mathrm{IM}$ 에 대 해서는 적극적 $\mathrm{IM}$ 과는 달리 연구가 많지는 않 지만 면접 평가와 부적 관계(예: Gundersen et al., 1996)에서부터 정적 관계(예: Tsai et al., 2010)에 이르기까지 혼재된 결과가 있었다.

이러한 정직한 $\mathrm{IM}$ 과 기만적 $\mathrm{IM}$ 이 구분되어 야 한다는 주장에 따라(Bourdage et al., 2018), 각각을 구분하여 면접 평가와의 관계를 탐색 한 결과, 부적 관계부터 정적 관계에 이르기 까지 혼재된 결과를 보인 기만적 $\mathrm{IM}$ 과는 달 리, 정직한 $\mathrm{IM}$ 은 비교적 일관적으로 면접 평 가와 정적 관계를 보였다(Bourdage et al., 2018; Levashina \& Campion, 2007; Swider et al., 2011). 예를 들어, 자기홍보(정직한 자기초점 $\mathrm{IM}$ )는 면접 점수(Swider et al., 2011) 및 고용 평가 (Bourdage et al., 2018)와 정적인 관계를 보인 반면, 기만적 자기초점 $\mathrm{IM}$ 은 각 준거변인과 부적 관계를 보이거나 유의한 관련성을 보이 지 않았다. Bourdage 등(2018)은 타인초점 IM과 
방어적 $\mathrm{IM}$ 에 대해서도 정직-기만적 $\mathrm{IM}$ 을 비교 하였는데, 기만적 환심사기 및 기만적 방어(이 미지 보호)와는 달리 정직한 환심사기와 정직 한 방어는 평가와 정적으로 유의한 관계를 보 였다. 요약하면, 다소 혼재된 결과가 나타나지 만 대체로 $\mathrm{IM}$ 은 면접 평가와 관련성이 있음을 알 수 있다. 특히, 정직한 $\mathrm{IM}$ 이 기만적 $\mathrm{IM}$ 보 다 면접 평가와 강한 정적 관계를 보인다. 반 면, 기만적 $\mathrm{IM}$ 은 면접 평가와 혼재된 결과를 보이거나 유의한 관련성을 보이지 않는다. 이 러한 선행연구를 기반으로 본 연구에서는 다 양한 $\mathrm{IM}$ 중 특히 정직한 $\mathrm{IM}$ 에 초점을 맞추 었다.

\section{사회경제적 지위(SES)}

SES는 위계적인 사회적 구조 내 개인의 위 치를 의미하며, 객관적 SES와 주관적 SES로 구 분된다. 객관적 SES는 개인이 소유한 금융자본 이나 교육기회 접근권과 같은 물질적 조건을 의미하며 전통적으로 수입, 교육, 직업의 3 가 지 요소를 측정해왔다(Oakes \& Rossi, 2003). 하 지만 객관적 SES 측정 및 해석의 어려움(Kraus et al., 2009; Liu et al., 2004)과 더불어 객관적 인 지표보다 주관적인 SES가 심리적 기능 및 건강(예: 안정시 심박수, 체지방 분포, 당뇨병, 감기) 관련 변인들과 더 강한 관계를 가진다 는 연구들(예: Adler et al., 2000; Cohen et al., 2008; Singh-Manoux et al., 2003) 및 심지어 동물들에게서도 집단 내 상대적 위치와 건 강 간의 정적 관계가 나타난다는 연구들(예:

Blanchard et al., 1993; Kaplan \& Manuck, 1999; Sapolsky, 1982)이 축적되면서 연구자들은 사회 계층 내 자신의 상대적 위치에 대한 주관적 인식을 의미하는 주관적 $\mathrm{SES}$ 에 더 주목하게
되었다(Kraus et al., 2012). 이러한 상대적 순위 기반의 주관적 SES는 객관적 SES와는 중간 정도의 상관만을 보이는 상호 구분되는 개 념으로 받아들여지고 있다(Adler et al., 2000; Goodman et al.. 2001).

사회계층은 사회적 위계 내의 다른 사람에 대한 순위(rank) 개념을 가지기에, 단순히 수입, 교육수준과 같은 객관적 측정치 이상의 것일 수 있다(Adler et al., 2000; Kraus et al., 2009; Singh-Manoux et al., 2003). Boyce 등(2010)에 따 르면, 사회적 삶에서 물질적 조건에 대한 해 석은 타인과의 물질적 자원에 대한 비교를 통 해 이루어진다. 다시 말해 물질적 자원에 대 한 비교 우위 수준이 사회계층의 순위를 결정 한다는 것이다. Kraus 등(2012)은 사회인지적 접근을 바탕으로 이러한 물질적 자원과 물질 적 자원에 대한 비교를 통해 형성되는 사회계 층의 서열이 사회인지 성향을 형성하고 행동 을 유도한다고 하였다. 따라서 객관적 SES와 주관적 $\mathrm{SES}$ 간 관계에서, 주관적 $\mathrm{SES}$ 는 객관적 $\mathrm{SES}$ 보다 더 근거리 개념으로 객관적 SES(수입, 교육수준, 직업)가 관찰가능한 행동(observable behavior, 예: 취향, 의복, 매너)을 통해 사회적 상호작용 과정에서 나타나고, 이것이 다시 사 회계층에 대한 순위 지각을 형성하며, 주관적 으로 지각한 본인의 순위가 건강, 통제감, 위 협지각 및 사회인지 성향에 영향을 주는 것으 로 볼 수 있다(Kraus et al., 2013). 이러한 개념 적 구분과 경험적 연구들을 근거로, 본 연구 는 특히 주관적 $\mathrm{SES}$ 에 주목하여 채용면접 장 면에서 SES가 IM의 사용에 미치는 영향을 살 펴보았다. 
$\mathrm{SES}$ 와 정직한 인상관리(IM): 통제감의 매개 효과

사회문화적 관점에서 개인은 사회계층적 배에 따라 특정한 물질적.사회적 조건에 노출 되며(Stephens \& Townsend, 2013), 이에 따라 개 인의 문화적 성향(예: 언어표현 방식, 사고방 식, 취미, 심미안 등, Bourdieu, 1984)과 상호의 존적 또는 독립적 자기개념이 다르게 형성된 다(Cohen \& Varnum, 2016; Kraus et al., 2012; Rucker et al., 2018). 구체적으로 노동계층은 상 위계층보다 더 상호의존적인 경향이 있으며 (Carey \& Markus, 2017), 자기애(narcissism), 심 리적 특권의식(psychological entitlement), 독특함 등을 표현하려는 경향성이 약하다(Piff, 2014; Snibbe \& Markus, 2005). Carey와 Markus(2017)에 따르면, 사회계층은 자기개념에 영향을 미쳐, 사회계층이 낮은 사람들은 보다 관계적인 자 기 관점을 취하여 다른 사람들과 연결되어 있 고 상호의존적이라고 지각하며, 그들에게 자 신을 맞추어 결속을 유지하고 조화(harmony)를 이루는 것을 강조하는 경향이 있다. 반면, 사 회계층이 높은 사람들은 타인들과 분리되어 자율적이고 독립된 자아를 가지며, 자신의 고 유한 특질(traits)이나 기질(dispositions)에 더 주 의를 기울이고, 개인의 목표와 자기홍보에 집 중하는 경향이 있다.

이와 유사하게 사회인지적 관점을 바탕으로 Kraus 등(2012, p. 159)은 SES가 낮은 사람들은 "외적인 제약, 외부의 위협 및 주변 타인들에 의해 동기부여되는 외부적 지향”인 맥락주의 적 성향(contextualist tendencies)이 강한 반면, $\mathrm{SES}$ 가 높은 사람들은 "본인의 목표, 동기, 정 서(goals, motivations, emotions) 등의 내적 상태 에 의해 동기부여되는 개인주의적 지향”을
의미하는 유아론(唯我論)적 사회인지 성향 (solipsistic social cognitive tendencies)이 강하다는 일반화된 결과를 보여주었다. 이들에 따르면 SES가 낮은 사람들이 맥락주의적 성향이 강한 이유는 생애 과정에서 겪어 온 일들의 성패 (成敗)에 통제할 수 없는 외부 요인이 더 강하 게 작용했기 때문이다. 반대로 상대적으로 SES 가 높은 사람들은 풍부한 물적 자원을 보유하 기에 사건에서의 성공 여부에 외적 자원의 제 한은 적고, 자신의 목표, 동기, 정서 등의 내 적 상태가 상대적으로 중요하게 작용한다. 즉 SES가 높은 사람들은 성향적(dispositional) 귀인 양식을 가지고 있어 사건의 성패에 있어서 개 인 내부의 요인을 보다 중시하는 경향이 있다. 이러한 차이는 사회적 사건의 귀인에서 뿐만 아니라 사회 환경에 대한 인지나 타인과의 관 계 등 여러 차원에서 작용하는 것으로 나타났 다(Kraus et al., 2012). 예를 들어, Kraus 등 (2010)은 가상의 직무면접에서 면접결과의 이 유를 설명하게 하였을 때, 주관적 SES가 낮은 사람들이 자신의 결과에 대해 기질적 요인보 다 상황적 요인으로 설명하려는 경향이 있다 는 것을 발견하였다. 다시 말해, 주관적 SES가 낮은 사람들은 면접 성과에 영향을 미치는 환 경적 요소에 관심을 기울이는 경향이 있었다. 본 연구에서는 이러한 SES에 따른 사회인지 성향의 차이가 면접에서의 IM 사용에도 영향 을 미칠 수 있으리라고 예측하였다. 구체적으 로 유아론적 사회인지 성향을 가진 SES가 높 은 사람들은 자신의 능력이나 역량과 같은 자기초점적인 방식으로 자신의 경험에 대해 설명하는 것이 익숙한 반면, SES가 낮은 사람 들은 이러한 방식에 익숙하지 않을 가능성이 있다.

앞서 언급했던 Sandal 등(2014)은 10 개국 대 
학생들을 대상으로 직무면접 장면에서 $\mathrm{IM}$ 의 유사개념인 자기 제시 책략에서의 문화 차이 를 조사하였다. 이들은 타인이나 물리적 환경 에 대한 통제를 강조하는 지배(mastery) 지향 문화의 학생들과 사회 속에서의 조화(harmony) 지향 문화의 학생들을 비교하였는데, 여기서 지배 지향 문화는 상황이나 환경에 대한 내부 통제를 강조하는 성향적 귀인양식 혹은 독립 적 관점과, 조화 지향 문화는 상호의존적·관 계적 관점과 연결될 수 있다. 이들의 연구에 서 조화를 추구하는 문화권의 학생들은 지배 지향 문화의 학생들보다 주장성이나 개인의 탁월함 강조와 같은 자기 제시 책략을 덜 사 용하는 것으로 나타났다. 이 연구는 국가 간 문화 차이에 초점을 두었지만, SES에 따라 문 화적 성향 및 자기개념에서 차이가 있음을 고 려하였을 때 이 결과를 SES와 IM 간 관계에도 적용해 볼 수 있다. 구체적으로 자기홍보가 지원자가 특정한 관점, 가치, 지식, 특질, 경험 등을 지녔음을 드러내며 자신의 탁월성에 초 점을 맞춰 긍정적인 이미지를 얻기 위한 책략 (Levashina et al., 2014; Tedeschi \& Norman, 1985)인 점을 고려하면 조화를 강조하는 낮은 $\mathrm{SES}$ 를 가진 사람들보다는 SES가 높은 사람들 이 더 선호하는 책략일 수 있다. 또한, 이는 자기에게 초점을 맞추는 책략으로서 SES가 높 은 사람들이 선호하는 유아론적 인지 성향과 밀접히 관련되어 있다. 이에 덧붙여 Kraus 등 (2009)은 SES의 객관적 지표보다는 주관적 지 표가 사회적 설명(social explanation)의 일관적인 예측변인임을 밝혔다. 구체적으로 주관적 SES 가 낮은 참가자들은 맥락적 설명양식을 선호 하였지만, 객관적 SES와 맥락적 설명양식 간 관계는 일관적이지 않았다. 따라서 주관적 SES 가 정직한 자기초점 $\mathrm{IM}$ (자기홍보)과 관계가 있
을 것이라고 예상할 수 있다.

정직한 방어 또한 동일한 논리를 적용해볼 수 있다. 방어적 책략은 지원자가 자신의 고 유한 이미지를 유지하기 위해 사용하는 IM으 로 본인의 내적 성향이나 가치를 우선시한다 는 점에서 역시 유아론적 성향과 연결될 수 있다. 이상을 바탕으로, 다음과 같은 가설을 설정하였다.

가설 1. 주관적 $\mathrm{SES}$ 는 면접장면에서 정직한 자기초점 $\mathrm{IM}(1 \mathrm{a})$ 및 정직한 방어적 $\mathrm{IM}(1 \mathrm{~b})$ 의 사용을 정적으로 예측할 것이다.

통제감(sense of control)은 사회적 행위와 그 결과에 대해서 자신이 영향력을 행사할 수 있 는 정도에 관한 믿음을 의미한다(Lachman \& Weaver, 1998). 통제감은 Skinner(1996)의 통제 에 관한 이중 개념화(two-fold conceptualization of control)에 근거하여 개인적 숙달(personal mastery)과 지각된 제약(perceived constraints)으로 구성된다. 개인적 숙달은 목표를 성취하는 과 정에서 느끼는 자기효능감을 의미하며, 지각 된 제약은 본인의 통제를 벗어나 목표 성취에 방해가 되는 방해요소의 존재 정도를 의미한 다. 다시 말해, 상황 통제감은 목표 달성과정 에서 자기효능감을 높게 느끼고, 방해요소의 존재 정도를 낮게 지각하여 자신에게 벌어지 는 일이나 결과를 자신이 통제할 수 있다는 신념을 의미한다.

Kraus 등(2009)은 SES와 사회적 사건에 대한 설명양식 간의 관계를 통제감이 매개하는 결 과를 보여주면서, SES가 낮은 사람들이 사회적 사건에 대해 맥락주의적 설명을 선호하는 이 유가 통제감을 낮게 지각하기 때문이라고 설 명하였다. 앞서 언급하였듯이, SES가 높은 사 
람들에게는 일에서의 성공 여부에 외적인 자 원의 제한이 적고 자신의 내적 상태가 상대적 으로 중요하게 작용하여 독립되고 자율적인 자기를 강조하고 특질이나 기질과 같은 개인 내부의 요인에 집중하므로(Carey \& Markus, 2017) 사건의 성패가 개인 내부의 요인에 달 려 있다고 지각하는 경향이 있다(Kraus et al., 2012). 반면, SES가 낮은 집단에서는 본인이 통 제할 수 없는 사건을 많이 경험하여, 자기효 능감이 낮고, 결과에 대해 운명 또는 권력을 가진 타인의 역할을 높게 지각하기 때문에, 통제감을 낮게 지각하게 된다(Gurin \& Brim, 1984; Lachman, 1985; Levenson, 1981).

주관적·객관적 SES와 맥락주의적 설명양식 간 관계에서와 마찬가지로 Kraus 등(2009)의 연구에서는 객관적 SES보다 주관적 SES가 통 제감과 높은 관계를 가진다는 것을 보여주었 다. 이를 바탕으로 본 연구에서는 특히 주관 적 $\mathrm{SES}$ 와 통제감 간의 관계에 주목하여, 다음 과 같은 가설을 도출하였다.

가설 2. 주관적 $\mathrm{SES}$ 는 통제감을 정적으로 예측할 것이다.

통제감과 $\mathrm{IM}$ 간의 관계를 직접적으로 탐색 한 연구는 드물다. 통제의 소재가 내부에 있 다는 신념을 의미하는 내적 통제소재(internal locus of control)와 IM 간의 관계를 탐색한 연 구들이 있지만, 정직한 $\mathrm{IM}$ 과 기만적 $\mathrm{IM}$ 을 구 분하지 않았으며, 이에 다소 혼재된 결과를 보여주었다(예: Delery \& Kacmar, 1998; Peeters \& Lievens, 2006). 본 연구에서는 자신의 실제 능력이나 성과를 전달하는 정직한 $\mathrm{IM}$ 인지 거 짓으로 꾸며낸 정보를 전달하는 기만적 $\mathrm{IM}$ 인 지에 따라 지원자의 통제감 정도가 $\mathrm{IM}$ 의 사용
에 미치는 영향이 다를 것으로 보았다.

Kraus 등(2009)은 사회인지적 관점을 바탕 으로 SES가 맥락적 혹은 유아론적 설명양식 에 미치는 영향을 통제감이 매개한다고 설명 하였다. 앞서 언급하였듯이, 통제감은 사건이 나 결과를 자신이 통제할 수 있다는 믿음으 로서, 통제감이 높은 사람들은 사회적 사건이 나 행동에 대한 성향적 원인을 과대평가하고 상황적 원인의 관점에서 사회적 결과를 설명 하려는 경향은 낮다(Kraus et al., 2009). 구체 적으로 주관적인 $\mathrm{SES}$ 가 낮다는 것은 더 적은 자원을 보유하며 타인과의 비교에서 하위계 층(subordinate rank)에 속한다는 것을 의미하는 데, 이러한 지각은 개인적인 통제감을 낮추고 (Gurin \& Brim, 1984; Lachman, 1986), 낮은 통 제감은 사회적 결과에 대해 내부적이고 기질 적인 원인을 경시하는 반면(예: Sechrist et al., 2004), 개인의 통제력 바깥에 있는 맥락적 요 인들로 설명하려는 경향을 갖게 한다(Jones \& Nisbett, 1987; Kelley, 1973). 이러한 설명양식은 의도적으로 꾸며낸 태도라기보다는 삶에서의 경험으로 인해 자연스럽게 형성된 사회인지적 성향으로 볼 수 있다(Kraus et al., 2011). 다시 말해 주관적 SES가 높은 사람들은 높은 통제 감으로 인해 사회적 사건 및 결과들을 설명하 기 위해 자기에 초점을 맞추는 반면, 주관적 SES가 낮은 사람들은 자신이 통제할 수 있는 부분이 적다고 지각하며 자기보다는 상황이나 맥락적 요인에 초점을 맞추는 경향이 있다. 앞서 살펴보았듯이, 주관적 $\mathrm{SES}$ 가 높은 사람들 이 높은 통제감을 가져 자신의 결과를 성향적 으로 설명하는 데 익숙한 반면, 낮은 SES 사람 들이 낮은 통제감으로 인해 맥락적인 요인으 로 설명하는 것에 익숙하다면, 면접장면에서 주관적 SES와 정직한 자기초점 IM 및 방어적 
IM 간의 관계를 통제감이 매개할 것으로 예측 할 수 있다. 구체적으로 정직한 자기초점 IM 이 자신의 경험이나 능력 등 자신의 자질에 초점을 맞춰서 스스로가 적합한 사람임을 강 조하는 것임을 고려할 때 통제감과 정적으로 연관될 것이며, 통제감은 주관적 SES와 자기초 점 $\mathrm{IM}$ 간의 관계를 매개할 것이다. 동일한 이 유로 통제감은 자신의 이미지와 능력에 초점 을 맞추는 정직한 방어와도 정적 관계를 가지 고 SES와 방어적 IM 간의 관계를 매개할 것으 로 예상할 수 있다.

가설 3. 통제감은 정직한 자기초점 $\operatorname{IM}(3 \mathrm{a})$ 및 정직한 방어적 $\mathrm{IM}(3 \mathrm{~b})$ 을 정적으로 예측할 것이다.

가설 4. 통제감은 주관적 SES와 정직한 자 기초점 $\mathrm{IM}(4 \mathrm{a})$ 및 정직한 방어적 $\mathrm{IM}(4 \mathrm{~b})$ 사용 간의 관계를 매개할 것이다.

$\mathrm{SES}$ 와 정직한 $\mathrm{IM}$ 과의 관계 중 타인초점 책 략인 환심사기에 대해서는 상기의 논리를 적 용하기에 무리가 있다. 환심사기는 개인의 내 적 가치에 중점을 두기보다는 타인의 의견이 나 가치에 동조해 상대의 환심을 사는 것에 우선적인 목적이 있기 때문이다. 앞서 언급하 였듯이 SES가 낮은 사람들은 높은 사람들에 비해 상호의존적인 성향을 띄고, 타인에게 맞 추려는 경향이 있는 반면(Carey \& Markus, 2017), 권력을 위해 타인에게 환심을 사고자 하는 것과 같은 정치적 행동을 불편하게 느낀 다는 연구도 있다(Belmi \& Laurin, 2016). 따라 서 SES가 면접 상황에서 환심사기 책략의 사 용에 어떤 영향을 미칠지는 명확하지 않으므 로, 따로 가설을 설정하지 않았다.

\section{$\mathrm{SES}$ 와 기만적 인상관리 $(\mathrm{IM})$}

$\mathrm{SES}$ 와 기만적 IM 간의 관계에 대한 예측은 정직한 $\mathrm{IM}$ 의 경우를 그대로 적용하기 힘들 다. Levashina와 Campion(2007)은 기만적 IM을 채용면접 장면에서의 의도적 거짓(faking) 행 위라고 정의하였다. 기만적 $\mathrm{IM}$ 은 상대방(면접 관)에게 보다 긍정적인 인상을 심어주거나 적 절한 대답을 전달하기 위하여 정보를 일부러 만들어 내거나 감추는 등의 왜곡 과정을 포 함한다. 긍정적 인상을 전달하려는 측면은 정 직한 $\mathrm{IM}$ 과 공유하는 부분이지만, 사실과 다 르게 의도적으로 정보를 만들어내거나 감추 는 가감(加減)적 측면은 윤리적인 측면과 연관되어 정직한 $\mathrm{IM}$ 과 구분되는 부분이다. 예를 들어, 기만적 $\mathrm{IM}$ 은 어두운 성격 3 요인 (dark triad)과 정적으로, 정직-겸손성 차원 및 통합성(integrity)과 부적으로 관련되어 있으며 (Melchers et al., 2020), 직무 및 훈련 장면에서 의 낮은 수행(Donovan et al., 2014; Schneider \& Powell, 2017) 뿐만 아니라 반생산적 업무행동 (counterproductive work behavior; Lortie \& Brooks, 2018)과 관련되어 있다.

일반적으로, 사회계층과 비윤리적 행동 (unethical behavior) 간의 관계를 다룬 연구들은 자신의 이익이 결부된 문제 상황에서 사회계 층이 높을수록 비윤리적 행동이 증가하는 것 을 보여주었다(Belmi \& Laurin, 2016; Dubois et al., 2015; Piff et al., 2012). 예를 들어, Dubois 등(2015)의 연구에서 사회계층이 높은 사람들 은 자기 이익과 관련된 사안에서 보다 비윤리 적으로 행동하였다. 본 연구에서는 면접장면 에서도 이러한 예측이 적용될 수 있는지 탐색 적으로 확인하고자 한다. 


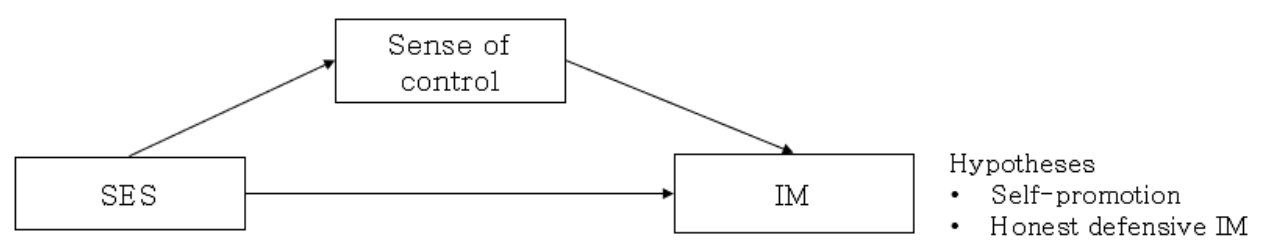

Figure 1. Research model

\section{방 법}

\section{연구대상 및 자료수집}

조사 시점에서 1년 내 공채나 인턴채용과정 에서 인성 면접을 본 경험이 있는 대학생들을 대상으로 온라인 및 오프라인 방식으로 설문 조사를 실시하였다. 가급적 한국의 전체 4년 제 대학생을 대표할 수 있도록 지역을 고려하 여 10 개 대학을 표집하였으며, 각 대학의 학 내 커뮤니티를 활용하여 주로 온라인으로 조 사하였다. 오프라인 설문은 1 저자가 소속된 대 학의 취업준비생들만을 대상으로 하였다. 설 문 앞부분에 응답자들이 면접 당시의 상황을 최대한 정확하게 회상할 수 있도록 면접유형, 면접관 유형, 면접 인원, 면접 시간, 블라인드 면접 여부, 그리고 가장 기억나는 면접 질문 에 대해 응답하도록 하였다. 설문에 참여한 총 응답자 수는 253명(남성: 108명, 여성: 140명, 무응답: 5명)이었으며, 평균 연령(SD)은 25.35 (2.28)세였다. 대부분 온라인을 통해 조사가 이 루어졌으며(241명), 일부 참여자의 경우 직접 설문지에 응답하였다(12명). 253명의 응답자 중 중간에 응답을 포기한 경우, 한 번호에만 응답한 경우, 불가능한 숫자를 적은 경우, 척 도의 순문항과 역문항이 유의한 역상관이 나 오지 않는 경우 등 18 명의 응답을 제거하여 분석에 사용된 최종 표본은 235 명이었다.
측정도구

\section{IM}

면접에서 $\mathrm{IM}$ 을 어느 정도 사용하였는지를 측정하기 위하여 Bourdage 등(2018)의 통합인 상관리 척도의 축약형 척도를 사용하였다. Bourdage 등(2018)은 새로 개발한 정직한 인상 관리(Honest Impression Management, HIM) 32문 항과 Levashina와 Campion(2007)이 개발한 기만 적 인상관리(Interview Faking Behabior, IFB) 54 문항을 축약하여 실용적 목적에서의 28 문항의 척도를 만들었다. 본 연구에서는 영역별로 네 문항씩 총 28 문항으로 구성된 축약형 척도를 사용하되, 대학생이라는 참가자의 특성상 이 미지 보호에서 과거 직무 경험에 대한 질문 2 문항을 삭제한 대신 $\mathrm{IFB}$ 의 이미지 보호에서 두 문항을 추가하였다. 추가된 문항은 “직무와 관련한 약점에 대해 직접적인 질문을 받았지 만, 실제 약점에 대해서는 말하지 않으려 했 다”와, “면접관이 물어본 질문 중에서 나의 채 용가능성을 낮출 수 있는 내용의 질문에 대해 서는 언급하지 않았다"였다. 따라서, 사용된 문항은 정직한 IM 12 문항(자기홍보, 정직한 환 심사기, 정직한 방어 각 네 문항), 기만적 $\mathrm{IM}$ 16 문항(가벼운 이미지 창조, 포괄적 이미지 창 조, 기만적 환심사기, 이미지 보호 각 네 문 항)이었다(부록 I, II 참조).

연구 참여자들은 제시된 문항을 읽고 당시 
면접 상황에서 자신의 행동과 얼마나 일치하 는 지를 리커트형 5 점 척도 $(1=$ 전혀 그렇지 않다, $3=$ 보통이다, $5=$ 매우 그렇다)상에 응답하였다. 자료 수집 후, 확인적 요인분석과 신뢰도 분석 과정에서 모형적합도와 하위 책 략별 신뢰도를 고려하여 포괄적 이미지 창조 의 한 문항을 제거하였다. 제거된 문항은 "나 의 자격요건이나 자질을 잘 드러내기 위해, 면접 전 또는 평소에 미리 만들어 둔 내용을 이야기했다"이었으며, 해당 문항이 제거되면서 신뢰도가 개선되었고(.67 $\rightarrow .71)$, 적합도(CFI, $\mathrm{GFI})$ 에서도 개선이 있었다 $.85, .86 \rightarrow .89$ 와 .88). 마지막으로 각 책략별로 평균을 내어 정 직한 $\mathrm{IM}$ 에서 3 개, 기만적 $\mathrm{IM}$ 에서 4 개의 지표 를 만들었다.

정직한 $\mathrm{IM}$ 에서 자기홍보의 신뢰도 계수 (Cronbach's a)는 .72, 정직한 환심사기의 신뢰 도는 .68 , 정직한 방어의 신뢰도는 .75로 나타 났으며, 기만적 $\mathrm{IM}$ 에서 가벼운 이미지 창조, 포괄적 이미지 창조, 기만적 환심사기, 이미지 보호의 신뢰도 계수는 각각 $.74, .71, .81, .70$ 이 었다.

확인적 요인분석(confirmatory factor analysis) 결과, 정직한 $\mathrm{IM}$ 의 3 요인 모형의 적합도 $\left(\chi^{2}(51)\right.$ $=122.55, \mathrm{CFI}=.90, \mathrm{GFI}=.92, \mathrm{RMSEA}=$ $.08)$, 기만적 $\mathrm{IM}$ 의 4 요인 모형의 적합도 $\left(\chi^{2}(86)\right.$ $=233.41, \mathrm{CFI}=.89, \mathrm{GFI}=.88, \mathrm{RMSEA}=$ .09)1) 모두 수용할만한 수준으로 나타났다.

1) 기만적 IM에 대해 3요인 모형(요인 1: 기만적 자 기초점 책략(가벼운 이미지 창조 + 포괄적 이미 지 창조), 요인 2: 기만적 환심사기, 요인 3: 이미 지 보호)으로 확인적 요인분석한 결과 $\chi^{2}(87)=$ 472.48, $\mathrm{CFI}=.71, \mathrm{GFI}=.81, \mathrm{RMSEA}=.14$ 로 적합도 지수가 현저하게 떨어졌다.

\section{통제감}

Lachman과 Weaver(1988)가 개발한 12문항을 번역하여 통제감을 측정하였다. 4 문항은 개인 적 숙달(personal mastery)을, 8 문항은 지각된 제 약(perceived constraints)을 측정하며, 5점 리커트 형 척도 $(1=$ 전혀 그렇지 않다, $3=$ 보통이다, $5=$ 매우 그렇다) 상에 응답하였다. 개인적 숙 달과 지각된 제약의 예시 문항으로는 각각 "나에게 일어날 일들의 대부분은 내가 하기 나름이다"(개인적 숙달), "나는 종종 내 인생이 이리저리 휘둘리고 있다고 생각한다"(지각된 제약) 등이 있다(부록 III 참조).

Kraus 등(2009)의 연구와 동일하게 통제감의 단일 측정치를 다음과 같이 계산하였다. 먼저 개인적 숙달 4 문항과 지각된 제약을 역채점한 8 문항의 총점을 각각 구하였다. 개인적 숙달 과 지각된 제약(역채점) 총점의 상관계수는 $.51(p<.01)$ 이었다. 두 차원을 동등하게 반영 하는 통제감 단일 측정치를 얻기 위해 두 총 점을 각각 표준화하여 합하였다. 통제감의 신 뢰도는 개인적 숙달 .85 , 지각된 제약 .84 였으 며 둘을 합친 전체 12 문항의 신뢰도는 .87 이 었다.

\section{SES}

주관적 SES를 측정하기 위해 맥아서 주관 적 SES 척도(MacArthur scale of subjective social status)의 성인용 버전을 사용하였다(Adler et al., 2000). 이 척도는 사회계층 순위를 측정하기 위해 가장 널리 사용되는 척도로서(Kraus et al., 2012), 교육수준, 소득, 직업 지위의 세 요 소를 고려하여 10 개의 가로대가 놓인 수직의 사다리 속에서 본인이 어디에 속하는지를 주 관적으로 평정하는 척도이다. 비교집단은 자 신이 다니는 대학이 아닌 전국 성인으로 설정 
하였으며, 제일 아래 위치한 1 에서 제일 위에 위치한 10 까지 수직으로 위치한 10 개의 가로 대에서 선택하도록 하였다. 전체 응답자들의 평균(SD)은 5.72(1.72)였다.

객관적 SES는 Kraus 등(2009)의 연구와 동일 하게 현재의 소득과 부모의 교육수준으로 측 정하였다. 소득수준의 경우에는 8 가지 범주 1 $=1$ 천만 원 이하, $2=1$ 천-3천만 원, $3=3$ 천-5천만 원, $4=5$ 천-7천만 원, $5=7$ 천-9천 만 원, $6=9$ 천 -1 억 1 천만 원, $7=1$ 억 1 천 2 억원, $8=2$ 억 이상)를 제시하여 가족연평균 소득을 측정하였으며, 평균(SD)은 3.90(1.77)이 었다. 부모 교육수준의 경우에는 부친과 모친 의 최종학력을 측정하였다. 학력은 6 가지 $(1=$ 중학교 졸업, 2 = 고등학교 졸업, $3=2$ 년제 전문대학 졸업, $4=4$ 년제 대학 졸업, $5=$ 석 사학위 취득, $6=$ 박사학위 취득) 범주로 나 누어 제시하였다. 부친 최종학력의 평균(SD)은 $3.55(1.25)$, 모친 최종학력의 평균(SD)는 3.00 (1.18)이었다. Kraus 등(2009)의 연구에 근거하 여 가족연평균소득 수준, 부친의 최종학력, 모 친의 최종학력의 3 개 문항을 각각 표준화하여 합산 점수를 구하였고 이를 객관적 $\mathrm{SES}$ 의 단 일 측정치로 사용하였다.

\section{통제변수}

종속변수인 $\mathrm{IM}$ 의 사용에 영향을 미칠 수 있는 인구통계적 변수 및 외향성을 통제하였 다. 인구통계적 변수로 성별, 나이와 더불어 면접 경험이 많을수록 $\mathrm{IM}$ 의 사용 빈도가 더 많을 것으로 예상하여 인성면접 경험의 횟수 를 측정하여 통제하였다. 인성면접 경험 횟수 는 공채 인성면접과 인턴 인성면접의 횟수를 합산하여 계산하였다. 응답자들의 공채 인성 면접 경험 횟수의 평균(SD)은 3.46(4.23), 인턴
인성면접 경험의 평균(SD)은 1.66(1.82)이었다.

선행연구에서 외향성은 $\mathrm{IM}$ 의 사용을 유의 미하게 예측했다. 외향적 지원자는 내향적 지 원자에 비해 정직한 $\mathrm{IM}$ 을 더 많이 사용하는 경향이 있었으며(Seo, 2015), 면접장면에서 외 향적인 지원자들은 자기홍보 책략과 정직한 환심사기 책략을 더 많이 사용하였다(Bourdage et al., 2015; Kristof-Brown et al., 2002). 따라서 본 연구는 외향성을 통제변인으로 사용하였다. Goldberg(1992)의 성격 5요인 척도(Big-Five factor markers)를 Guay 등(2013)이 한국어로 번역하여 타당화한 10 문항의 외향성 척도를 사용하였다. 문항의 예로는 "대화를 먼저 시작하는 편이 다"와 "모임에서 나를 잘 드러내지 않는다(R)" 등이 있다. 제시된 문항을 읽고 얼마나 동의 하는지를 리커트형 5점 척도(1=전혀 그렇지 않다, $3=$ 보통이다, $5=$ 매우 그렇다)상에 응답 하게 하였으며, 신뢰도는 .91이었다.

\section{결 과}

\section{기술통계 및 상관관계}

본 연구에서 측정된 변인들에 대한 평균, 표준편차, 상관계수를 Table 2에 제시하였다. 먼저, $\mathrm{IM}$ 의 사용 빈도를 살펴보면, 가장 많이 사용되는 책략은 자기홍보 $(\mathrm{M}=3.81, \mathrm{SD}=$ .69)로 “면접관이 내가 가진 역량을 파악할 수 있도록 역량과 관련된 과거 경험을 이야기”하 는 행동이었으며 $(\mathrm{M}=4.04, \mathrm{SD}=0.97)$, 가장 적게 사용되는 책략은 포괄적 이미지 창조(M $=2.57, \mathrm{SD}=.93)$ 로 "실제로 없었던 상황이 나 성공경험을 지어"내는 행동 $(\mathrm{M}=2.11, \mathrm{SD}$ $=1.23$ )과 "적절한 대답을 할 수 없을 때는 
한국심리학회지: 산업 및 조직

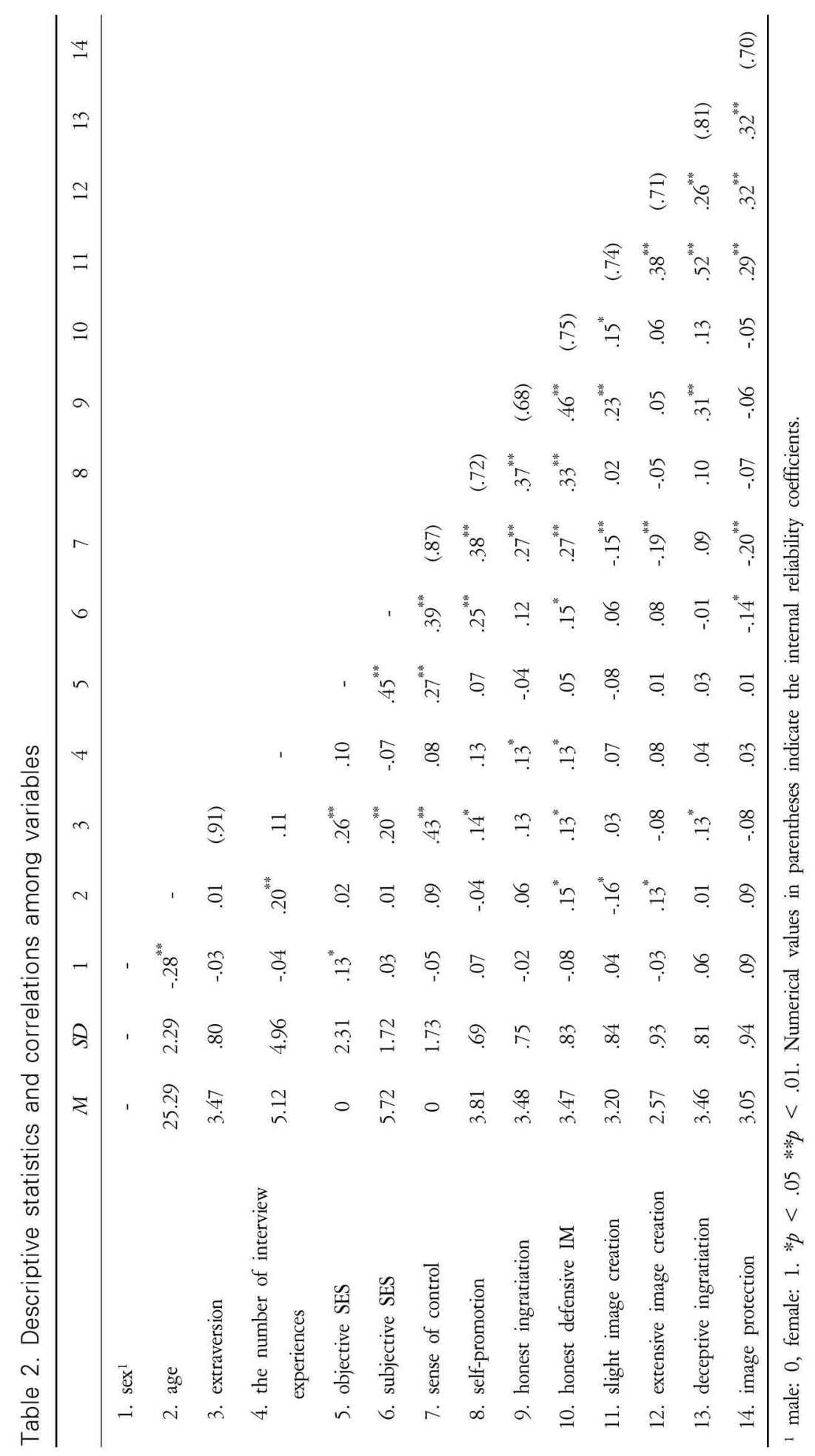


다른 사람의 경험을 빌려서 마치 내 것처럼 말"하는 행동 $(\mathrm{M}=2.11, \mathrm{SD}=1.23)$ 이었다.

인구통계적 변수 중 연령은 가벼운 이미지 창조와는 부적 관계 $(r=-.16, p<.05)$, 정직한 방어 및 포괄적 이미지 창조와는 정적 관계 (각각 $r=.15, .13, p_{s}<.05$ )를 가졌으며, 면접 경험 횟수는 정직한 환심사기 및 정직한 방어 와 정적인 관계를 가졌다 $\left(r_{s}=.13, p_{s}<.05\right)$. 외향성은 자기홍보와 정직한 방어(각각 $r=$ $\left..14, .13, p_{s}<.05\right)$ 및 기만적 환심사기 $(r=.13$, $p<.05)$ 와 정적인 관계를 보였다. 정직한 $\mathrm{IM}$ 책략 간 상관관계(.33 $\left.\leq r_{s} \leq .46, p_{s}<.01\right)$ 와 기만적 $\mathrm{IM}$ 책략 간 상관관계. $26 \leq r_{s} \leq .52$, $\left.p_{s}<.01\right)$ 는 모두 유의했다. 정직한 환심사기는 가벼운 이미지 창조 $(r=.23, p<.01)$ 및 기만 적 환심사기 $(r=.31, p<.01)$ 와 정적으로, 정 직한 방어는 가벼운 이미지 창조 $(r=.15, p<$ .05)와 정적으로 관련되어 있었다. 가설 3 과 관련하여, 통제감은 대부분의 $\mathrm{IM}$ 과 유의한 관 계를 가졌으며 정직한 $\mathrm{IM}$ 의 책략들과는 정적 관계 $\left(.26 \leq r_{s} \leq .38, p_{s}<.01\right)$ 를, 기만적 $\mathrm{IM}$ 의 책략들과는 기만적 환심사기를 제외하고 $(t$ $=.09, p>.05)$ 부적 관계(-.21 $\leq r_{s} \leq-.15, p_{s}$ $<.01)$ 를 보였다.

객관적 - 주관적 SES 간에는 중간 정도의 정 적 상관관계 $(r=.45, p<.01)$ 가 있었다. 가설 2 와 관련하여, 통제감은 객관적-주관적 $\mathrm{SES}$ 모두와 정적 관계를 가졌다(각각 $r=.27, .39$, $\left.p_{s}<.01\right)$. 가설 1 과 관련하여, $\mathrm{SES}$ 와 $\mathrm{IM}$ 간 관 계를 살펴보았을 때 객관적 SES는 어떤 IM과 도 유의한 관계를 보이지 않은 반면, 주관적 $\mathrm{SES}$ 는 자기홍보 $(r=.25, p<.01)$ 및 정직한 방어 $(r=.15, p<.05)$ 와 유의한 정적 관계를 가졌다. 마지막으로 기만적 $\mathrm{IM}$ 의 네 개 책략 에 대해 주관적 SES는 유일하게 이미지 보호
와 부적인 관계를 보였다 $(r=-.14, p<.05)$.

\section{가설검증 및 연구질문 분석}

Hayes(2013)의 Process Macro를 이용해 주관적 $\mathrm{SES}$ 와 정직한 자기초점(가설 1a) 및 방어적 $\mathrm{IM}$ (가설 $1 \mathrm{~b})$ 간 관계에 대한 통제감의 매개효 과(가설 $2,3 \mathrm{a}, 3 \mathrm{~b}$ ) 검증을 실시하였다. 통제변 수로는 연령, 성별, 외향성 및 면접경험 횟수 를, 독립변수로 주관적 $\mathrm{SES}$ 를 투입하였고, 자 기홍보와 정직한 방어 각각에 대해 매개분석 을 실시하였다(Table 3, Table 4 참조).

주관적 SES는 인구통계적 변인 및 외향성을 통제하고도 자기홍보 $(\beta=.25, p<.01)$, 정직 한 방어 $(\beta=.15, p<.05)$ 및 통제감을 정적 으로 예측하였으며 $(\beta=.31, p<.01)$, 따라서 가설 1,2 가 지지되었다. 통제감 역시 자기홍 보 $(\beta=.40, p<.01)$ 와 정직한 방어 $(\beta=.24$, $p<.01$ 를 정적으로 예측하였다(가설 3 지지). 간접효과를 검증하기 위해 부트스트랩 검증 (bootstrap estimation approach)을 실시하였으며 5,000 개의 부트스트랩 샘플을 추출하여 $95 \%$ 신뢰구간을 추정하였다. 그 결과 신뢰구간은 0 을 포함하지 않은 것으로 나타나 매개효과가 유의한 것으로 확인되었고 간접효과의 값은 Table 4와 같이 나타났다(가설 4 지지).

마지막으로, 본 연구에서는 탐색적으로 주 관적 $\mathrm{SES}$ 와 정직한 환심사기 및 기만적 $\mathrm{IM}$ 의 네 개 책략과의 관계를 살펴보고자 하였다. Table 2의 상관분석 결과에서 주관적 SES는 기 만적 $\mathrm{IM}$ 중 이미지 보호와 유의한 부적인 관 계를 보였다 $(r=-.14, p<.05)$. 상기의 통제변 수(연령, 성별, 외향성, 면접경험 횟수)를 통제 하였을 때 주관적 SES가 이미지 보호와 유의 한 관련이 있는지 확인하기 위해, 위계적 회 
한국심리학회지: 산업 및 조직

Table 3. Hypotheses verification

\begin{tabular}{|c|c|c|c|c|c|c|c|c|c|c|}
\hline & \multicolumn{2}{|c|}{ sense of control } & \multicolumn{4}{|c|}{ self-promotion } & \multicolumn{4}{|c|}{ honest defensive IM } \\
\hline & Model I & Model II & Model I & Model II & Model III & Model IV & Model I & Model II & I Model III & Model IV \\
\hline sex & -.02 & -.03 & .07 & .06 & .07 & .07 & -.04 & -.05 & -.04 & -.04 \\
\hline age & .07 & .06 & -.05 & -.06 & -.08 & -.08 & .11 & .11 & .09 & .09 \\
\hline $\begin{array}{l}\text { the number of } \\
\text { interview experiences }\end{array}$ & .02 & .05 & .13 & $.15^{*}$ & .12 & $.14^{*}$ & .10 & .12 & .10 & .11 \\
\hline extraversion & $.42^{* *}$ & $.35^{* *}$ & .11 & .05 & -.06 & -.07 & .09 & .06 & -.01 & -.01 \\
\hline subjective SES & & $.31^{* *}$ & & $.25^{* *}$ & & $.14^{*}$ & & $.15^{*}$ & & .08 \\
\hline sense of control & & & & & $.40^{* *}$ & $.35^{* *}$ & & & $.24^{* *}$ & $.22^{* *}$ \\
\hline$R^{2}$ & .18 & .27 & .04 & .09 & .16 & .18 & .04 & .06 & .09 & .10 \\
\hline$F$ & $12.62^{* *}$ & $16.75^{* * *}$ & 2.05 & $4.60^{* * *}$ & $8.79^{* * *}$ & $8.20^{* *}$ & $2.54^{*}$ & $3.02^{*}$ & $4.50^{* *}$ & $4.00^{* * *}$ \\
\hline
\end{tabular}

$* p<.05 * * p<.01$.

Table 4. Results of bootstraps $(5,000)$ for indirect effects(mediation)

\begin{tabular}{cccccc}
\hline & Boot & & \multicolumn{2}{c}{ 95\% Confidence Interval } \\
\cline { 3 - 7 } & coefficient & Boot S.E. & LLCI & ULCI \\
\hline subjective SES $\rightarrow$ sense of control $\rightarrow$ self-promotion & .04 & .01 & .02 & .07 \\
\hline subjective SES $\rightarrow$ sense of control $\rightarrow$ Honest defensive IM & .03 & .01 & .01 & .06 \\
\hline
\end{tabular}

Table 5. The effects of subjective SES on image protection

\begin{tabular}{ccc}
\hline & \multicolumn{2}{c}{ image protection } \\
\cline { 2 - 3 } age & Model I & Model II \\
\hline sex & .13 & .13 \\
the number of interview experiences & .12 & .13 \\
extraversion & -01 & -.00 \\
subjective SES & -.06 & -.03 \\
\hline$R^{2}$ & .03 & .05 \\
$F$ & 1.53 & 2.10 \\
\hline
\end{tabular}

$* p<.05 * * p<.01$.
귀분석을 실시한 결과(Table 5), 주관적 SES는 이미지 보호에 유의한 부(-)의 영향을 미치는 것으로 나타났지만 $(\beta=-.14, p<.05)$, 이미지 보호를 예측하는 회귀분석 모형은 유의하지 않았다 $[F 5,224)=2.10, p=.07]$. 또한 주관 적 SES는 통제변수들을 투입한 이후에도 그 외의 다른 책략들(정직한 환심사기, 가벼운 이 미지 창조, 포괄적 이미지 창조, 이미지 보호) 을 예측하지 못했다. 마지막으로 통제변수를 투입하였을 때 객관적 SES가 IM을 예측하는지 살펴보았다. 위계적 회귀분석 결과 객관적 SES 는 정직한 $\mathrm{IM}$ 및 기만적 $\mathrm{IM}$ 중 어떤 것도 예 측하지 못했다 $\left(p_{s}>.10\right)$. 


\section{논 의}

면접장면에서 IM은 만연한 현상으로 대 부분의 지원자들은 면접 과정 중 적어도 한 번은 정직하거나 기만적인 $\mathrm{IM}$ 을 사용한다 (Bourdage et al., 2018; Weiss \& Feldman, 2006). 하지만 주된 사용 책략이나 그 빈도는 다를 수 있다. 본 연구에서는 주관적 SES가 면접장 면에서 지원자들의 IM에 어떠한 영향을 미치 는지를 살펴보았다. 구체적으로 본 연구에서 는 $\mathrm{SES}$ 에 대한 사회인지적 접근을 면접장면에 적용하여 주관적 $\mathrm{SES}$ 가 정직한 $\mathrm{IM}$ 중 자기홍 보 및 정직한 방어와 정적인 관계를 가질 것 이며, 그 관계를 통제감이 매개할 것이라고 예측하였다. 분석 결과, 주관적 SES는 통제감 (가설 2), 정직한 자기홍보 및 방어책략을 정 적으로 예측하였으며(가설 1), 통제감 역시 정 직한 자기홍보 및 방어책략과 정적인 관계를 보였고(가설 3), 부트스트랩 분석 결과, 매개 효과가 유의한 것으로 나타났다(가설 4). 오프 라인 참가자(12명)를 제외하고 온라인 참가자 (223명)만을 대상으로 분석을 시행하였을 때도 이 결과는 동일하게 나타났다. 탐색적으로 주 관적 $\mathrm{SES}$ 와 정직한 환심사기(정직한 타인초점 $\mathrm{IM}$ ) 및 기만적 $\mathrm{IM}$ 간의 관계를 살펴본 결과, 이들 간의 관계는 유의하지 않았다. 객관적 $\mathrm{SES}$ 는 정직한-기만적 $\mathrm{IM}$ 중 어떤 것과도 유 의한 관계를 보이지 않았다. 이것은 다양한 심리사회적 요인이 주관적 $\mathrm{SES}$ 와 더 밀접한 관련이 있음을 보여주는 다른 연구 결과들과 일치하며(예: Adler et al., 2000; Goodman et al., 2001; Kraus et al., 2009), 상대적 순위 개념이 포함된 주관적 SES가 물질적 자원 보유 여부 에 기초한 객관적 SES와는 구별되는 개념이라 는 것을 재차 시사한다.

\section{이론적 시사점}

본 연구는 채용면접 장면에서 주관적 SES와 $\mathrm{IM}$ 의 다양한 책략 중 정직한 자기초점 $\mathrm{IM}$ 과 방어적 IM 간의 관계를 통제감이 매개한다는 것을 보여주었다. 이 주제는 세 가지 방식으 로 의미가 있다. 첫째, 면접은 조직에 들어가 기 위한 최종 관문의 역할을 한다는 점에서 SES에 따라 면접 내 행동이 달라지는지 여부 를 파악할 필요가 있으며, 둘째, 다양한 면접 행동 중 채용면접 상황에서 가장 일상적으로 일어나는 $\mathrm{IM}$ 에 초점을 맞추었다. 특히 $\mathrm{IM}$ 은 면접결과에 영향을 미치기 때문에(Kacmar \& Carlson, 1999; Kristof-Brown et al., 2002), 탐색 할만한 가치가 있다. 마지막으로 채용면접은 개인에게 중대한 결과가 타인에게 달려 있다 는 점에서 극적으로 통제감의 상실을 경험하 는 장면이다. 이러한 관점에서 매개변인으로 삶의 경험에 의해 형성된 비교적 만성적인 통 제감의 역할을 살펴보는 것은 의미가 있다.

채용장면에서 SES의 영향에 대한 관심이 증 가하고 있음에도(예: Amis et al., 2020; Fang \& Saks, 2020; Rivera \& Tilcsik, 2016), SES와 IM 간 관계에 대해 살펴본 연구는 찾기 어려웠다. SES가 높은 지원자들에 비해 낮은 지원자들은 채용과정에서 불이익을 경험할 수 있다. 이러 한 불이익은 SES가 낮은 지원자들에 대한 면 접관 및 인사담당자들의 암묵적인 편향 때문 에 야기될 수도 있고, SES에 따른 구직자의 행 동이나 전략에서의 차이로 발생할 수도 있다. Fang과 Saks(2020)는 SES가 낮은 구직자들이 면 접 수가 많더라도 SES가 높은 사람만큼 직무 제안을 받지 못했다는 것을 보여주었지만, SES 가 높은 사람들이 면접에서 성공할 확률이 높 은 이유를 밝히지는 못했다. 본 연구는 SES에 
따라 채용장면에서 구직자의 행동이 어떻게 달라지는지에 대한 탐색적 연구로서, SES가 낮 은 지원자들이 실제로 면접에서 통과하는 비 율이 상대적으로 낮은지는 조사하지 못했지만, 주관적 SES가 높을 때 정직한 $\mathrm{IM}$, 그중에서도 자기홍보와 정직한 방어를 더 많이 사용하는 경향이 있다는 것을 보여주었다. 정직한 $\mathrm{IM}$ 은 면접에서 더 긍정적인 평가로 이어진다는 선 행연구(Bourdage et al., 2018; Swider et al., 2011) 를 고려할 때, SES에 따른 정직한 IM 사용의 차이가 SES가 낮은 사람들이 면접에 통과되기 어렵게 만들 가능성이 있으며, 향후 연구에서 이에 대해 탐색해볼 필요가 있다.

둘째, 본 연구에서는 SES에 따라 사회인지 성향이 다르다는 선행연구(예: Kraus et al., 2012)를 토대로, 통제감을 도입하여 SES와 IM 간 관계를 설명하고자 하였다. SES는 단순한 물질적 자원 보유 여부를 넘어 계층적 의미를 가짐으로써, 인간의 다양한 성향, 태도 및 행 동 양태에서의 차이를 낳는다. 이러한 차이는 SES가 낮은 사람들이 자신이 통제할 수 없는 환경적 사건을 빈번히 경험하면서 통제감을 낮게 지각하기 때문일 수 있다(Kraus et al., 2012). 본 연구에서는 채용장면에서 SES와 IM 사용 간 관계를 설명하는 심리적 기제로서 통 제감의 역할을 보여주었다. 본 연구는 면접장 면에서의 구직자의 행동에 초점을 두었지만, SES에 따라 통제감의 수준이 다르다면 조직 구성원의 태도나 행동에도 SES가 영향을 미칠 수 있을 것이다. 예를 들어, 통제감이 높은 사람들은 진로 적응성(career adaptibility)이 더 높고(Duffy, 2010), 직업 스트레스(occupational stress)가 낮으며(Karimi \& Alipour, 2011), 직무만 족과 직무수행이 높다(Judge et al., 2003). 이처 럼 조직 장면에서 개인의 심리적 통제감의 중
요성을 고려해볼 때, 향후 연구에서는 조직 장면에서 다양한 직무 및 경력 관련 변인들에 대한 SES의 영향을 더 면밀하게 검토할 필요 가 있다.

마지막으로, 본 연구에서는 주관적 $\mathrm{SES}$ 와 객관적 SES를 구분하여 관심 변인과의 관계를 살펴보았다. 주관적 $\mathrm{SES}$ 는 객관적 $\mathrm{SES}$ 와 $r=$ .45 로 중간 정도의 상관관계를 보였으며, 주관 적 $\operatorname{SES}(r=.39)$ 와 객관적 $\operatorname{SES}(r=.27)$ 모두 통제감을 정적으로 예측하는 것으로 나타났다. 하지만 주관적 SES와는 달리 객관적 SES는 IM 의 사용을 예측하지 못했다. 이 결과는 주관 적 SES가 객관적 SES와 구분되는 개념으로서, 통제감이나 사회인지 성향에 대한 근거리 예 측변인임을 주장한 Kraus 등(2013)의 모형과 일관된다. 이 모형에 따르면 객관적 SES에 대 한 신호(signal)가 관찰가능한 행동으로 전달되 어 사회적 상호작용 과정에서 주관적인 사회 계층 순위 지각(주관적 $\mathrm{SES}$ )이 형성되고, 이러 한 계층의식이 개인의 심리적 경험 패턴에 영 향을 미친다. 본 연구는 이러한 객관적 SES와 주관적 SES 간 관계 및 효과에 대한 경험적 증거를 제공하였다는 점에서도 의미가 있다.

\section{실무적 시사점}

본 연구는 다음과 같은 실무적 함의를 가진 다. 첫째, 정직한 $\mathrm{IM}$ 의 사용(특히 자기홍보)이 면접 평가와 정적 관계에 있음을 보여준 선행 연구(예: Bourdage et al., 2018)와 SES와 정직한 책략 간의 정적 관계를 보여준 본 연구의 결 과를 같이 고려해보면, SES는 면접 평가 및 채 용 가능성과 관련될 수 있다. SES가 높은 사람 들이 독립적이고 개인지향적이며 자신의 내적 상태에 좀 더 주의를 기울인다면, SES가 낮은 
사람들은 보다 상호의존적이며 조화와 적응을 강조하고 관계지향적인 경향이 있다(Carey \& Markus, 2017; Kraus et al., 2012). Kraus 등 (2009)은 더 나아가 SES에 따라 사회인지 성향 에서 차이가 나타난다고 하였다. 본 연구에서 는 이러한 차이 때문에 $\mathrm{IM}$ 의 사용에서 차이가 나타날 수 있음을 보여주고 있다. 만약 사회 계층이 높은 지원자들이 면접장면에서 이득을 본다면, 조직은 의도치 않게 상대적으로 높은 $\mathrm{SES}$ 를 가진 종업원들로 구성된 동질적 집단이 될 수 있다. 조직 구성원들의 사회경제적 배 경의 유사성은 집단사고(Janis, 1991) 및 도덕적 해이(Stiglitz, 1990) 등을 야기할 수 있다. 일례 로, 경영진들의 사회경제적 배경의 동질성으 로 인한 집단사고 현상은 미국의 엔론(Enron) 사태의 주요한 원인 중의 하나로 지목되었다 (O'Connor, 2003). 조직은 채용과정에서 지원자 들의 SES가 채용 결정에 미치는 영향을 신중 하게 고려할 필요가 있다.

둘째, 면접장면은 바라는 결과에 대한 결정 권이 타인(예: 면접관)에게 있기 때문에 통제 감이 약화되고 무력감을 느끼기 쉬운 대표적 인 상황이다(Lammers et al., 2013). 본 연구에서 통제감은 기만적 환심사기를 제외한 모든 IM 과 관련되어 있었으며, $\mathrm{SES}$ 에 따른 $\mathrm{IM}$ 의 차 이를 일정 부분 설명할 수 있었다. 본 연구에 서는 통제감을 삶의 경험에서 형성된 비교적 안정적인 성향으로 간주하였지만, 통제감은 일시적으로도 조작될 수 있다. 예를 들어, Lammers 등(2013)은 참가자들에게 가상의 직무 면접 상황에서 권력을 가졌거나 무력감을 느 꼈던 경험에 대해 쓰게 함으로써 통제감을 조 작하였는데, 권력을 가졌던 경험을 상기한 참 가자들은 지원서(실험 1)와 면접(실험 2)에서 더 높은 평가를 받았으며, 이것은 참가자의
설득력에 대한 평가자의 지각에 의해 매개되 었다. 이러한 연구 결과에 근거할 때, 면접장 면은 상태(state)로서의 통제감을 최소로 느낄 수 있는 상황이지만, 평소 높은 수준의 통제 감을 보유한 지원자는 이런 장면에서도 좀 더 자신의 생각이나 행동에 대한 통제감을 느낄 것이며, 유효한 적응적 행동을 할 가능성이 높을 수 있다. 따라서, 진로상담가 및 교육자 들은 면접에서의 행동을 변화시키기 위해 통 제감에 대한 개입 방안을 강구할 필요가 있다.

셋째, 본 연구는 국내에서 확산되는 블라인 드 채용방식과 관련하여 시사점을 가진다. 이 는 직무능력만을 선발의 기준으로 삼고 선발 과정의 공정성을 기하기 위해 학력·지역·연 령-성별 등 지원자의 개인정보를 배제하는 채용방식을 의미한다. 하지만 SES에 따라 비언 어적 행동이 달라진다는 Piff 등(2010)의 연구 나 대인장면에서 짧은 시간의 노출만으로도 상대방의 SES에 대해 상당히 정확하게 파악할 수 있다는 Kraus와 Keltner(2009)의 연구 결과를 고려하였을 때, 면접장면에서 지원자의 SES는 다양한 방식으로 면접관에게 영향을 미치는 강력한 신호가 될 수 있다. 이에 주요한 인적 사항을 지원서에서 삭제하거나 면접 과정에서 관련 사항을 언급하지 않는 등의 현재의 블라 인드 채용방식만으로는 직무능력과 관계없는 지원자의 배경을 완전히 배제하기에는 불충분 할 수 있다. 조직 차원에서는 면접관의 교육 과정에서 SES에 따라 지원자의 행동양식이 달 라질 수 있음을 충분히 인식시켜야 하며, 이 러한 편향을 최소화하기 위한 교육 프로그램 을 수반해야 할 것이다. 또한 면접관을 선발 할 때 배경의 다양성을 고려하는 것도 한 가 지 방법이다. 일반적으로 사람들은 자신과 유 사한 사람들에게 매력을 느끼는 경향이 있다 
(Montoya et al., 2008). 면접관의 SES의 다양성 을 고려하지 않는다면 면접관은 대체로 높은 $\mathrm{SES}$ 를 가진 지원자들과 유사한 취미나 경험 및 행동양식을 공유하고(Fang \& Saks, 2020; Rivera, 2012), 이들에게 더 매력을 느낄 가능성 이 있으며, 이것은 다시 SES가 낮은 지원자를 비의도적으로 차별하는 결과로 나타날 수도 있다.

\section{본 연구의 한계 및 향후 연구 방안}

본 연구는 다음과 같은 한계를 가진다. 첫 째, 본 연구에서 사용한 통합인상관리 척도는 각 범주의 IM들을 얼마나 많이 사용하였는지 를 측정하고 있다. 그런데 본 연구에서는 책 략 사용 과정에서의 질적 측면은 다루지 못하 였다. 동일한 책략을 사용하더라도 사람에 따 라 효과성은 다를 수 있다. 예컨대, "나의 기 술과 능력을 면접관에게 확실히 알려주었다" 고 응답하더라도 어떤 지원자는 이를 더 효과 적으로 적용할 수 있을 것이다. 향후 연구에 서는 전문가 또는 제3의 관찰자가 효과성에 대한 평정을 하거나, 질적 측면을 포함하는 측정치를 개발하여 사용할 필요가 있다.

둘째, 본 연구에서는 설문을 통해 지원자가 면접 경험에 대해서 자기 보고식으로 응답하 도록 하였다. 따라서 동일 시점에서의 변인들 간의 상관관계에 기초하고 있기 때문에 동일 방법편의(common method bias) 문제를 배제하 기 어렵다. 향후 연구에서는 종단 연구 방법 으로 각 변수의 영향력 관계를 살펴볼 필요가 있다. 더 나아가, 과거의 경험에 대해 회상하 게끔 하였기 때문에 기억의 왜곡이 발생할 가 능성도 있다. 본 연구에서는 회상에서의 왜곡 문제를 최소화하기 위하여 당시 상황을 최대
한 떠올릴 수 있도록 여러 질문을 하였지만, 일정 한계가 있을 것이다. 이를 해결하는 한 가지 방법은 본인의 면접장면을 녹화하여 보 여줌으로써 해당 장면에서의 $\mathrm{IM}$ 의 사용 여부 를 검토하게 하는 것이다(Roulin et al., 2015). 더 나아가 본 연구에서 객관적 $\mathrm{SES}$ 는 $\mathrm{IM}$ 의 사 용과 유의한 관련성을 가지지 못했다. 비록 이 결과는 객관적 SES보다는 주관적 SES가 심 리적 경험 및 사회인지성향에 더 직접적인 영 향을 미친다는 선행연구(예: Kraus \& Keltner, 2013; Kraus et al., 2009)로 뒷받침되지만, 본 연구에서 발견한 주관적 SES와 IM 간 관계가 둘 모두 한 설문에서 자기보고식으로 측정되 었기 때문에 나타났을 가능성을 배제할 수 없다.

셋째, 본 연구에서는 선행연구의 절차(예: Kraus et al., 2009)에 따라 주관적 SES는 맥아 서 주관적 SES 척도를 사용하여 측정하였지만, 객관적 $\mathrm{SES}$ 의 경우에는 소득과 부모 학력을 각각 표준화하고 합산한 값을 사용하였다. 하 지만 소득과 부모 학력이 각기 다른 태도나 성향을 예측할 수 있으며, 범주변수를 연속변 수로 간주한 점에서 한계가 있다. 소득과 부 모 학력을 합산하지 않고 개별적으로 일곱 가 지 IM과의 상관관계를 확인하였을 때, 부모 학력과 IM은 유의한 관계를 보이지 않았지만 소득은 포괄적 이미지 창조와 정적 관계를 가 졌다 $(r=.17, p<.05)$. 추가로 통계청(2019)의 소득 5 분위별 가구소득 기준을 반영하여 참가 자들을 소득수준에 따라 세 집단으로 나누어 [상: 7천만 원 이상(5분위, 75 명), 중: 3천만 7 천만 원(3, 4분위, 105 명), 하: 3 천만 원 이하 (1, 2분위, 50명)]. 공분산분석을 시행한 결과 집단에 따라 포괄적 이미지 창조 책략의 사용 정도가 다른 것으로 나타났다 $[F(2,223)=$ 
5.07, $p<.01]$. 구체적으로 소득수준 상 집단 $(\mathrm{M}=2.82, \mathrm{SD}=.93)$ 은 중 집단 $(\mathrm{M}=2.50$, $\mathrm{SD}=.96)$ 및 하 집단 $(\mathrm{M}=2.42, \mathrm{SD}=.85)$ 에 비해 유의하게 높은 수준으로 포괄적 이미지 창조 책략을 많이 사용하였다 $\left(p_{s}<.05\right)$. 하지 만 부모 학력에 따른 집단 구분은 IM 사용을 예측하지 못했다. 비록 본 연구에서는 교육수 준이나 소득과 같은 SES를 구성하는 개별적인 요인보다는 사회계층적 위치가 IM에 미치는 효과에 초점을 맞추고 있기 때문에 주관적 $\mathrm{SES}$ 와 객관적 $\mathrm{SES}$ 의 두 가지 종류로 구분하여 $\mathrm{SES}$ 와 IM과의 관계를 살펴보았지만, 향후 연 구에서는 소득수준, 학력, 직업과 같이 객관적 $\mathrm{SES}$ 를 구성하는 다양한 요인들을 세분화해서 측정하여 그 효과를 심도 있게 살펴볼 필요가 있다.

넷째, 본 연구는 SES에 따라 $\mathrm{IM}$ 의 사용 양 상에 차이가 있음을 보여주었지만, 이것이 면 접 평가 및 이후 직무수행과 어떻게 연결되는 지는 확인하지 못했다. 채용면접은 그 특성상 $\mathrm{IM}$ 이 요구되는 대표적인 맥락으로서, 심지어 기만적 $\mathrm{IM}$ 이라고 하더라도 적절한 $\mathrm{IM}$ 의 사용 은 면접상황에서 적응적인 행동일 수 있다. 본 연구에서는 $\mathrm{SES}$ 와 $\mathrm{IM}$ 간의 관계를 살펴보 았지만, 향후 연구에서는 면접결과와 이후의 수행까지 포함하여 전체 경로에 대해 탐색할 필요가 있다. 또한, 사회인지적 관점의 논리상, $\mathrm{SES}$ 와 IM 간의 관계는 다양한 조직 장면에서 유사하게 나타날 수 있다. 채용면접은 대부분 어느 정도의 인상관리 행동이 요구되는 장면 이기 때문에 인상관리의 정도에 있어 변산이 적을 수 있다. 따라서 향후 연구에서는 $\mathrm{IM}$ 이 강하게 요구되지 않는 다른 조직 장면들에서 SES와 IM 간의 관계가 더 뚜렷하게 나타나는 지를 조사해볼 수 있을 것이다.
마지막으로, 본 연구에서는 면접장면에서 통제감에 초점을 맞추어 그 매개효과를 확인 하였다는 데서 강점이 있지만, 그 과정에서 통제소재(locus of control)와 같은 기질적인 요 인의 영향을 통제하지 못한 점을 한계로 볼 수 있다. 또한 향후 연구에서는 통제감과 같 은 심리적 변인 이외의 다른 매개변인들의 가 능성을 탐색할 필요가 있다. 예를 들어, SES에 따라 삶에서의 가용 자원이 다르기에 SES가 높은 사람들은 더 많은 교육 기회(예, 유학)나 경험(예: 해외연수)을 축적할 가능성이 있다. 그리고 이것은 면접장면에서 자신의 역량과 관련된 경험을 더 쉽게 드러낼 수 있는 자원 으로서 작용하여 정직한 자기초점 $\mathrm{IM}$ 의 증가 로 이어질 수 있다. 향후 연구에서는 이와 같 은 다양한 가능성을 고려하여 다양한 매개변 인을 확인하여야 할 것이다.

\section{참고문헌}

Adler, N. E., Epel, E. S., Castellazzo, G., \& Ickovics, J. R. (2000). Relationship of subjective and objective social status with psychological and physiological functioning: Preliminary data in healthy, White women. Health Psychology, 196), 586-592.

https://doi.org/10.1037/0278-6133.19.6.586

Adler, N. E., \& Ostrove, J. M. (1999). Socioeconomic status and health: what we know and what we don't. Annals of the New York academy of Sciences, 896(1), 3-15. https://doi.org/10.1111/j.1749-6632.1999.tb0810 $1 . \mathrm{x}$

Amis, J. M., Mair, J., \& Munir, K. A. (2020). 
The organizational reproduction of inequality. Academy of Management Annals, 14(1), 195-230. https://doi.org/10.5465/annals.2017.0033

Belmi, P., \& Laurin, K. (2016). Who wants to get to the top? Class and lay theories about power. Journal of Personality and Social Psychology, 111(4), 505-529.

https://doi.org/10.1037/pspi0000060

Blanchard, D., Sakai, R., McEwen, B., Weiss, S., \& Blanchard, R. (1993). Subordination stress: Behavioural, brain, and neuroendocrine correlates. Behavioural Brain Research, 58, 113-121. https://doi.org/10.1016/0166-4328(93)90096-9

Bourdage, J. S., Roulin, N., \& Tarraf, R. (2018). "I (might be) just that good": Honest and deceptive impression management in employment interviews. Personnel Psychology, 71(4), 597-632.

https://doi.org/10.1111/peps.12285

Bourdage, J. S., Wiltshire, J., and Lee, K. (2015). Personality and workplace impression management: correlates and implications. Journal of Applied Psychology, 100, 537-546. https://doi.org/10.1037/a0037942

Bourdieu, P. (1984). Distinction: A social critique of the judgement of taste. Cambridge, MA: Harvard University Press.

Boyce, C. J., Brown, G. D., \& Moore, S. C. (2010). Money and happiness: Rank of income, not income, affects life satisfaction. Psychological Science, 21(4), 471-475. https://doi.org/10.1177/0956797610362671

Carey, R. M., \& Markus, H. R. (2017). Social class shapes the form and function of relationships and selves. Current Opinion in Psychology, 18, 123-130.

https://doi.org/10.1016/j.copsyc.2017.08.031

Cohen, S., Alper, C. M., Doyle, W. J., Adler, N., Treanor, J. J., \& Turner, R. B. (2008). Objective and subjective socioeconomic status and susceptibility to the common cold. Health Psychology, 27, 268-274.

https://doi.org/10.1037/0278-6133.27.2.268

Cohen, A. B., \& Varnum, M. E. (2016). Beyond East vs. West: Social class, region, and religion as forms of culture. Current Opinion in Psychology, 8, 5-9. https://doi.org/10.1016/j.copsyc.2015.09.006

Delery, J. E., \& Kacmar, K. M. (1998). The Influence of Applicant and Interviewer Characteristics on the Use of Impression Management. Journal of Applied Social Psychology, 28(18), 1649-1669. https://doi.org/10.1111/j.1559-1816.1998.tb0133 9. $\mathrm{x}$

Dipboye, R. L. 1992. Selection interviews: Process perspectives. Cincinnati, $\mathrm{OH}$ : South-Western.

Donovan, J. J., Dwight, S. A., \& Schneider, D. (2014). The impact of applicant faking on selection measures, hiring decisions, and employee performance. Journal of Business and Psychology, 29, 479-493. https://doi.org/10.1007/s10869-013-9318-5

Dowd, J. B., Simanek, A. M., \& Aiello, A. E. (2009). Socio-economic status, cortisol and allostatic load: a review of the literature. International Journal of Epidemiology, 38(5), 1297-1309. https://doi.org/10.1093/ije/dyp277

Dubois, D., Rucker, D. D., \& Galinsky, A. D. 
(2015). Social class, power, and selfishness: When and why upper and lower class individuals behave unethically. Journal of Personality and Social Psychology, 108(3), 436-449. https://doi.org/10.1037/pspi0000008

Duffy, R. D. (2010). Sense of control and career adaptability among undergraduate students. Journal of Career Assessment, 18(4), 420-430. https://doi.org/10.1177/1069072710374587

Elliott, L. P., editor. (2015). New Oxfam Report Says Half of Global Wealth Held by the $1 \%$. Available from: http://www.theguardian.com/business/2015/jan/1 9/global-wealth-oxfam-inequality-davoseconomicsummit-switzerland.

Fang, R. T., \& Saks, A. M. (2020). Class advantage in the white-collar labor market: An investigation of social class background, job search strategies, and job search success. Journal of Applied Psychology. Advance online publication. https://doi.org/10.1037/apl0000842

Goldberg, L. R. (1992). The development of markers for the big-five factor structure. Psychological Assessment, 4(1), 26-42. http://dx.doi.org/10.1037/1040-3590.4.1.26

Goodman, E., Adler, N. E., Kawachi, I., Frazier, A. L., Huang, B., \& Colditz, G. A. (2001). Adolescents' perceptions of social status: development and evaluation of a new indicator. Pediatrics, 108(2), e31-e31. https://doi.org/10.1542/peds.108.2.e31

Guay, R. P., Oh, I., Choi, D., Mitchell, M. S., Mount, M. K., \& Shin, K. (2013). The interactive effect of conscientiousness and agreeableness on job performance dimensions in South Korea. International Journal of Selection and Assessment, 21(2), 233-238.

https://doi.org/10.1111/ijsa.12033

Gundersen, D. E., Tinsley, D. B., \& Terpstra, D. E. (1996). Empirical assessment of impression management biases: The potential for performance appraisal error. Journal of Social Behavior and Personality, 11(5), 57-74. https://doi.org/10.1300/J077V14N01_06

Gurin, P., \& \& Brim, O. G., Jr. (1984). Change in self in adulthood: The example of sense of control. In P. B. Baltes \& O. G. Brim, Jr. (Eds.), Life-span development and behavior (Vol. 6, pp. 218-334). New York: Academic Press.

Hayes, A. F. (2013) Introduction to mediation, moderation, and conditional process analysis: $A$ regression-based approach. New York, NY: Guilford Press.

Higgins, C. A., \& Judge, T. A. (2004). The effect of applicant influence tactics on recruiter perceptions of fit and hiring recommendations: a field study. Journal of Applied Psychology, 894), 622-632.

https://doi.org/10.1037/0021-9010.89.4.622

Huffcutt, A. I., \& Culbertson, S. S. (2011). Interviews APA Handbook of Industrial and Organizational Psychology (Vol. 2: Selecting and Developing Members for the Organization). Washington, DC: American Psychological Association, 185-203.

Ingram, P. (2021). The Forgotten Dimension of Diversity. Harvard Business Review, 99(1), 58-67.

Janis, I. (1991). Groupthink. In E. Griffin (Ed.) $A$ First Look at Communication Theory (pp. 235- 
246). New York: McGrawHill.

Jones, E. E., \& Nisbett, R. E. (1987). The actor and the observer: Divergent perceptions of the causes of behavior. In E. E. Jones, D. E. Kanouse, H. H. Kelley, R. E. Nisbett, \& S. Valins (Eds.), Attribution: Perceiving the causes of behavior (pp. 79 -94). Hillsdale, NJ: Erlbaum.

Judge, T. A., Erez, A., Bono, J. E., \& Thoresen, C. J. (2003). The core self evaluations scale: Development of a measure. Personnel Psychology, 562), 303-331.

https://doi.org/10.1111/j.1744-6570.2003.tb0015 2.x

Kacmar, K. M., \& Carlson, D. S. (1999).

Effectiveness of impression management tactics across human resource situations. Journal of Applied Social Psychology, 296), 1293 - 1315. https://doi.org/10.1111/j.1559-1816.1999.tb0204 0.x

Kacmar, K. M., Delery, J. E., \& Ferris, G. R. (1992). Differential Effectiveness of Applicant Impression Management Tactics on Employment Interview Decisions. Journal of Applied Social Psychology, 22(16), 1250-1272. https://doi.org/10.1111/j.1559-1816.1992.tb0094 $9 . \mathrm{x}$

Kaplan, J., \& Manuck, S. (1999). Status, stress, and atherosclerosis. Annals of the New York Academy of Sciences, 896, 145-161.

Karimi, R., \& Alipour, F. (2011). Reduce job stress in organizations: Role of locus of control. International Journal of Business and Social Science, 2(18), 232-236. Retrieved from https://www.ijbssnet.com/journals/Vol_2_No_18 _October_2011/28.pdf .
Kelley, H. H. (1973). The process of causal attribution. American Psychologist, 28(2), 107128. http://doi.org/10.1037/h0034225

Korea Employers Federation. (2017. 6). 2017 New Employee Recruitment Survey. https://www.kefplaza.com/kef/kef_press_view.jsp? num $=6023$

Korea National Statistical Office. (2019. 12), 2019 Household Financial Welfare Survey. http://kostat.go.kr/portal/korea/kor_nw/1/4/4/ind ex.board

Kraus, M. W., Côté, S., \& Keltner, D. (2010). Social class, contextualism, and empathic accuracy. Psychological Science, 21(11), 17161723. https://doi.org/10.1177/0956797610387613

Kraus, M. W., \& Keltner, D. (2009). Signs of socioeconomic status: A thin-slicing approach. Psychological Science, 201), 99-106. https://doi.org/10.1111/j.1467-9280.2008.02251.x

Kraus, M. W., \& Keltner, D. (2013). Social class rank, essentialism, and punitive judgment. Journal of Personality and Social Psychology, 105(2), 247-261. https://doi.org/10.1037/a0032895

Kraus, M. W., Piff, P. K., \& Keltner, D. (2009). Social class, sense of control, and social explanation. Journal of Personality and Social Psychology, 97(6), 992-1004. https://doi.org/10.1037/a0016357

Kraus, M. W., Piff, P. K., \& Keltner, D. (2011). Social class as culture: The convergence of resources and rank in the social realm. Current Directions in Psychological Science, 204), 246250. 
https://doi.org/10.1177/0963721411414654

Kraus, M. W., Piff, P. K., Mendoza-Denton, R., Rheinschmidt, M. L., \& Keltner, D. (2012). Social class, solipsism, and contextualism: How the rich are different from the poor. Psychological Review, 119, 546-572. https://doi.org/10.1037/a0028756

Kraus, M. W., Tan, J. J., \& Tannenbaum, M. B. (2013). The social ladder: A rank-based perspective on social class. Psychological Inquiry, 24(2), 81-96. https://doi.org/10.1080/1047840X.2013.778803

Kristof-Brown, A., Barrick, M. R., \& Franke, M. (2002). Applicant impression management: Dispositional influences and consequences for recruiter perceptions of fit and similarity. Journal of Management, 28(1), 27-46. https://doi.org/10.1177/014920630202800103

Kuznets, S. (1955). Economic Growth and Income Inequality. The American Economic Review, 45(1), 1-28. Retrieved February 17, 2021, from http://www.jstor.org/stable/1811581

Lachman, M. E. (1985). Personal efficacy in middle and old age: Differential and normative patterns of change. In G. H.Elder, Jr. (Ed.), Life-course dynamics: Trajectories and transitions, 1968-1980 (pp. 188-213). Ithaca, NY: Cornell University Press.

Lachman, M. E., \& Weaver, S. L. (1998). The sense of control as a moderator of social class differences in health and well-being. Journal of Personality and Social Psychology, 74(3), 763-773. https://doi.org/10.1037/0022-3514.74.3.763

Lammers, J., Dubois, D., Rucker, D. D., \& Galinsky, A. D. (2013). Power gets the job:
Priming power improves interview outcomes. Journal of Experimental Social Psychology, 494), 776-779.

https://doi.org/10.1016/j.jesp.2013.02.008

Leary, M. R., \& Kowalski, R., M. (1990). Impression management: A literature review and two-component model. Psychological Bulletin, 107(1), $34-47$.

https://doi.org/10.1037/0033-2909.107.1.34

Lee, K., \& Ashton, M. C. (2004). Psychometric properties of the HEXACO Personality Inventory. Multivariate Behavioral Research, 39(2), 329-358. https://doi.org/10.1207/s15327906mbr3902_8

Levashina, J., \& Campion, M. A. (2006). A model of faking likelihood in the employment interview. International Journal of Selection and Assessment, 14(4), 299-316. https://doi.org/10.1111/j.1468-2389.2006.00353.x Levashina, J., \& Campion, M. A. (2007). Measuring faking in the employment interview: Development and validation of an interview faking behavior scale. Journal of Applied Psychology, 92(6), 1638-1656. https://doi.org/10.1037/0021-9010.92.6.1638

Levashina, J., Hartwell, C. J., Morgeson, F. P., \& Campion, M. A. (2014). The structured employment interview: Narrative and quantitative review of the research literature. Personnel Psychology, 67(1), 241-293. https://doi.org/10.1111/peps.12052

Liu, W. M., Ali, S. B., Soleck, G., Hopps, J., Dunston, K., \& Pickett, T. (2004). Using social class in counseling psychology research. Journal of Counseling Psychology, 51(1), 3-18. 
https://doi.org/10.1037/0022-0167.51.1.3

Lortie, B. C., \& Brooks, M. E. (2018, April). Investigating the predictors and outcomes of interview faking behavior. Paper presented at the $33^{\text {rd }}$ Annual Meeting of the Society for Industrial and Organizational Psychology, Chicago, IL.

Mankiw, N. G. (2015). Yes, r> g. so what? American Economic Review, 105(5), 43-47. https://doi.org/10.1257/aer.p20151059

McLaren L. (2007). Socioeconomic status and obesity. Epidemiologic Reviews, 29(1), 29 - 48. https://doi.org/10.1093/epirev/mxm001

Melchers, K. G., Roulin, N., \& Buehl, A. K. (2020). A review of applicant faking in selection interviews. International Journal of Selection and Assessment, 28(2), 123-142. https://doi.org/10.1111/ijsa.12280

Montoya, R. M., Horton, R. S., \& Kirchner, J. (2008). Is actual similarity necessary for attraction? A meta-analysis of actual and perceived similarity. Journal of Social and Personal Relationships, 25(6), 889-922. https://doi.org/10.1177/0265407508096700

Na, J., Chan, M. Y., Lodi-Smith, J., \& Park, D. C. (2018). Social-class differences in self-concept clarity and their implications for well-being. Journal of Health Psychology, 23(7), 951-960.

https://doi.org/10.1177/1359105316643597

Nazroo, J. Y. (1998). Genetic, cultural or socio economic vulnerability? Explaining ethnic inequalities in health. Sociology of Health \& Illness, 20(5), 710-730. https://doi.org/10.1111/1467-9566.00126
Oakes, J. M., \& Rossi, P. H. (2003). The measurement of SES in health research: Current practice and steps toward a new approach. Social Science \& Medicine, 56(4), 769-784 https://doi.org/10.1016/S0277-9536(02)00073-4

O'Connor, M. A. (2003). The Enron Board: The Perils of Groupthink. University of Cincinnati Law Review, 71, 1233-1320.

OECD Inequality Update. (2016). Income inequality remains high in the face of weak recovery. Paris: Organization for Economic Cooperation and Development.

Peck, J. A., \& Levashina, J. (2017). Impression management and interview and job performance ratings: A meta-analysis of research design with tactics in mind. Frontiers in Psychology, 8, 201.

https://doi.org/10.3389/fpsyg.2017.00201

Peeters, H., \& Lievens, F. (2006). Verbal and nonverbal impression management tactics in behavior description and situational interviews. International Journal of Selection and Assessment, 14(3), 206-222.

https://doi.org/10.1111/j.1468-2389.2006.00348.x

Piff, P. K. (2014). Wealth and the inflated self: Class, entitlement, and narcissism. Personality and Social Psychology Bulletin, 40(1), 34-43. https://doi.org/10.1177/0146167213501699

Piff, P. K., Kraus, M. W., Côté, S., Cheng, B. H., \& Keltner, D. (2010). Having less, giving more: The influence of social class on prosocial behavior. Journal of Personality and Social Psychology, 995), 771-784. https://doi.org/10.1037/a0020092 
Piff, P. K., Stancato, D. M., Côté, S., Mendoza-Denton, R., \& Keltner, D. (2012). Higher social class predicts increased unethical behavior. Proceedings of the National Academy of Sciences, 10911), 4086-4091.

https://doi.org/10.1073/pnas.1118373109

Piketty, T. (2014). Capital in the Twenty-First Century, Cambridge, MA: Harvard University Press.

Rivera, L. A. (2012). Hiring as cultural matching: The case of elite professional service firms. American Sociological Review, 77, 999-1022. http://dx.doi.org/10.1177/0003122412463213

Rivera, L. A., \& Tilcsik, A. (2016). Class advantage, commitment penalty: The gendered effect of social class signals in an elite labor market. American Sociological Review, 81(6), 1097-1131.

https://doi.org/10.1177/0003122416668154

Rosenfeld, P. (1997). Impression management, fairness, and the employment interview. Journal of Business Ethics, 16(8), 801-808.

https://doi.org/10.1023/A:1017972627516

Roulin, N., Bangerter, A., \& Levashina, J. (2014). Interviewers' perceptions of impression management in employment interviews. Journal of Managerial Psychology. 29, 141-162. https://doi.org/10.1108/JMP-10-2012-0295

Roulin, N., Bangerter, A., \& Levashina, J. (2015). Honest and deceptive impression management in the employment interview: Can it be detected and how does it impact evaluations? Personnel Psychology, 68(2), 395-444. https://doi.org/10.1111/peps.12079

Rucker, D. D., Galinsky, A. D., \& Magee, J. C.
(2018). The agentic-communal model of advantage and disadvantage: How inequality produces similarities in the psychology of power, social class, gender, and race. Advances in Experimental Social Psychology, 58, 71-125. https://doi.org/10.1016/bs.aesp.2018.04.001

Sandal, G. M., van de Vijver, F., Bye, H. H., Sam, D. L., Amponsah, B., Cakar, N., ... \& Tien-Lun Sun, C. (2014). Intended self-presentation tactics in job interviews: A 10-country study. Journal of Cross-Cultural Psychology, 45(6), 939-958. https://doi.org/10.1177/0022022114532353

Sapolsky, R. (1982). The endocrine stress-response and social status in the wild baboon. Hormones and Behaviour, 15, 279-292. https://doi.org/10.1016/0018-506X(82)90027-7

Schlenker, B. R. (1980). Impression management: The self-concept, social identity, and interpersonal relations. Monterey, CA: Brooks/Cole.

Schneider, L., \& Powell, D. (2017, April). Does deceptive impression management predict job performance? Paper presented at the 32nd Annual Conference for the Society for Industrial and Organizational. Orlando, FL: Psychology.

Sechrist, G. B., Swim, J. K., \& Stangor, C. (2004). When do the stigmatized make attributions to discrimination occurring to the self and others? The roles of self-presentation and need for control. Journal of Personality and Social Psychology, 87(1), 111-122. https://doi.org/10.1037/0022-3514.87.1.111

Seo, J. W. (2015). The effects of interviewee's introversion-extraversion on impression management 
tactic usage and interview evaluation during an interview. unpublished master dissertation. Sogang University, Seoul, South Korea.

Singh T, Sharma S, \& Nagesh S. (2017). Socioeconomic status scales updated for 2017. International Journal of Research in Medical Sciences. 5, 3264-3267.

http://dx.doi.org/10.18203/2320-6012.ijrms2017 3029

Singh-Manoux, A., Adler, N. E., \& Marmot, M. G. (2003). Subjective social status: Its determinants and its association with measures of ill-health in the Whitehall II study. Social Science \& Medicine, 56, 1321-1333.

https://doi.org/10.1016/S0277-9536(02)00131-4

Skinner, E. A. (1996). A guide to constructs of control. Journal of Personality and Social Psychology, 71(3), 549-570.

https://doi.org/10.1037/0022-3514.71.3.549

Snibbe, A. C., \& Markus, H. R. (2005). You Can't Always Get What You Want: Educational Attainment, Agency, and Choice. Journal of Personality and Social Psychology, $88(4), 703-720$. https://doi.org/10.1037/0022-3514.88.4.703

Stephens, N. M., Markus, H. R., \& Phillips, L. T. (2014). Social class culture cycles: How three gateway contexts shape selves and fuel inequality. Annual Review of Psychology, 65, 611-634.

http://dx.doi.org/10.1146/annurev-psych-010213115143.

Stephens, N. M., \& Townsend, S. S. (2013). Rank is not enough: Why we need a sociocultural perspective to understand social class.
Psychological Inquiry, 24(2), 126-130.

https://doi.org/10.1080/1047840X.2013.795099

Stern, I., \& Westphal, J. D. (2010). Stealthy footsteps to the boardroom: Executives' backgrounds, sophisticated interpersonal influence behavior, and board appointments. Administrative Science Quarterly, 55(2), 278-319. https://doi.org/10.2189/asqu.2010.55.2.278

Stiglitz, J. E. (1990). Peer monitoring and credit markets. The World Bank Economic Review, 4(3), 351-366. https://doi.org/10.1093/wber/4.3.351

Swider, B. W., Barrick, M. R., Harris, T. B. \& Stoverink, A. C. (2011). Managing and creating an image in the interview: The role of interviewee initial impressions. Journal of Applied Psychology, 966), 1275-1288. https://doi.org/10.1037/a0024005

Tedeschi, J. T., \& Melburg, V. (1984). Impression management and influence in the organization. In S. B. Bacharach \& E. J. Lawler (Eds.), Research in the sociology of organizations: 31-58. Greenwich, CT: JAI.

Tedeschi, J. T., \& Norman, N. (1985). Social power, self-presentation, and the self. In B. R. Schlenker (Ed.), The self and social life (pp. 291-322). New York: McGraw-Hill.

Tsai, W., Huang, T., Wu, C., \& Lo, I. (2010). Disentangling the effects of applicant defensive impression management tactics in job interviews. International Journal of Selection and Assessment, 18(2), 131-140. https://doi.org/10.1111/j.1468-2389.2010.00495.x Turnley, W. H., \& Bolino, M. C. (2001). Achieving desired images while avoiding 
undesired images: exploring the role of selfmonitoring in impression management. Journal of Applied Psychology, 86(2), 351-360.

https://doi.org/10.1037/0021-9010.86.2.351

Van Iddekinge, C. H., McFarland, L. A., \& Raymark, P. H. (2007). Antecedents of impression management use and effectiveness in a structured interview. Journal of Management, 33(5), 752-773

https://doi.org/10.1177/0149206307305563
Weiss, B., \& Feldman, R. S. (2006). Looking good and lying to do it: Deception as an impression management strategy in job interviews. Journal of Applied Social Psychology, 364), 1070-1086.

https://doi.org/10.1111/j.0021-9029.2006.00055.x

투고일자 : 2021. 03. 15 수정일자 : 2021. 07. 15. 확정일자 : 2021. 08. 07. 


\section{The effect of socio-economic status on impression management (IM)

\author{
in the employment interview: \\ The mediating effect of the sense of control
}

Youngdo Kim

Jae Yoon Chang

Department of Psychology,

Sogang University,
Sanghee Nam

Department of Psychology,

Chungbuk University

This study investigated the effect of socio-economic status (SES) on honest IM (self-promotion, honest ingratiation, honest defensive impression management) and deceptive IM (slight image creation, extensive image creation, deceptive ingratiation, image protection) in employment interview, and examined the mediating effect of sense of control. For this purpose, a survey was conducted on 235 university students with employment interview experiences. The results showed that subjective SES had a positive association with self-promotion and honest defensive IM of honest IM, and this relationship was mediated by sense of control. However, subjective SES was not associated with honest ingratiation of honest IM, nor with any tactic of deceptive IM. While objective SES was positively associated with sense of control, objective SES had no statistically significant relationship with honest and deceptive IM. The current study provided meaningful implication as it emphasized the role of SES in the employment interview by identifying behavioral differences among job applicants with varying SES, and providing basic explanation on the effect of SES by clarifying the role of sense of control.

Key words : socio-economic status, employment interview, honest impression management, deceptive impression management, sense of control 


\section{부 록}

부록 1: 정직한 IM (5점 Likert 척도 사용)

1. 지원 직무 분야와 관련된 나의 자격을 면접관이 확실하게 파악하도록 노력하였다

2. 내가 가진 좋은 지원자로서의 자질을 면접관에게 확실히 보여주었다.

3. 나의 기술과 능력을 면접관에게 확실히 알려주었다

4. 면접관이 내가 가진 역량을 파악할 수 있도록 역량과 관련된 과거 경험을 이야기 했다.

5. 면접관이 가진 가치나 관점 중 나와 비슷한 것이 있는지 알아내려 했고 그것에 대해 언급 했다.

6. 면접관이 나와 유사한 관점을 드러냈을 때, 그것들을 최대한 답변에 담아내려고 하였다.

7. 나는 회사의 가치와 목표 중 내가 공유하는 것을 찾아내었고, 그것들을 강조하기 위해 노 력하였다.

8. 면접관과 내가 동일하게 관심 가진 이슈나 주제에 대해 논의했다.

9. 과거에 내가 특정한 상황에 대처했던 방식에 대한 아쉬운 점과 앞으로 어떻게 개선할 지 에 대해 이야기 했다.

10. 과거의 좋지 않았던 일에 대해 왜 그 결과가 초래될 수밖에 없었는 지 솔직하게 설명 했다.

11. 과거에 일어났던 부정적인 사건이나 상황이 재발하지 않도록 내가 어떻게 했는지를 면접 관에게 자세히 설명했다.

12. 내 책임이었던 과거의 실패 경험이 어떻게 나에게 도움이 되었는지 설명하였다.

주1) 1-4: 자기홍보, 5-8: 정직한 환심사기, 9-12: 정직한 방어

부록 2: 기만적 IM (5점 Likert 척도 사용)

1. 이전에 내가 했던 일들에서 내가 맡았던 역할을 과장해서 이야기했다.

2. 면접관의 반응이나 코멘트에 따라 나의 생각을 바꿔서 답변했다.

3. 면접관이 기대하고 있는 내용에 맞춰서 내 답변을 변경했다.

4. 나의 가치와 목표가 회사의 가치와 목표와 합치된다는 점을 과장해서 말했다.

5. 나의 자격요건이나 자질을 잘 드러내기 위해, 면접 전 또는 평소에 미리 만들어 둔 내용 을 이야기했다.*

6. 나의 과거 경험들을 논리적이고 그럴듯한 이야기로 만들어 냈다.

7. 실제로 없었던 상황이나 성공경험을 지어냈다

8. 적절한 대답을 할 수 없을 때는 다른 사람의 경험을 빌려서 마치 내 것처럼 말했다.

9. 직무와 관련한 약점에 대해 직접적인 질문을 받았지만, 실제 약점에 대해서는 말하지 않 으려 했다.

10. 과거에 겪었던 문제들에 대해 직접적인 질문을 받았지만 의도적으로 몇가지는 애기하지 
않았다.

11. 면접관이 물어본 질문 중에서 나의 채용가능성을 낮출 수 있는 내용의 질문에 대해서는 언급하지 않았다

12. 나의 약점이나 치부에 대해서는 말하지 않았다.

13. 면접관이 중요하게 생각하는 것을 파악하여 그것이 마치 내 생각이었던 것처럼 답변했다

14. 면접관이 지닌 관점/견해와 일치하는 방향으로 내 의사를 표현하려고 노력했다.

15. 면접관이 지닌 가치, 관점, 신념과 비슷해 보이려고 노력했다.

16. 나는 회사와 관련된 사항에 대해, 내겐 별 의미가 없더라도, 최대한 경의를 표하려고 했다.

주1) 1-4: 가벼운 이미지 창조, 5-8: 포괄적 이미지 창조, 9-12: 이미지 보호, 13-16: 기만적 환 심사기

*삭제된 문항

\section{부록 3: 통제감 (5점 Likert 척도 사용)}

1. 내가 마음 먹은 일은 무엇이든지 할 수 있다.

2. 무언가를 진심으로 하고자 할 때 나는 보통 성공할 수 있는 방법을 찾아낸다.

3. 내가 원하는 것을 얻을 수 있을지 없을 지는 나에게 달려있다.

4. 나에게 일어날 일들의 대부분은 내가 하기 나름이다.

5. 내가 할 수 있는 것과 할 수 없는 것의 대부분을 다른 사람들이 정한다.

6. 내 인생에 있어서 중요한 것들을 바꾸기 위해 내가 할 수 있는 일은 거의 없다.

7. 내 인생의 여러 문제들을 해결하는 데 있어 종종 무기력함을 느낀다.

8. 내 인생에서 일어나는 일은 종종 내 통제를 벗어난다.

9. 내가 하고 싶은 일에는 많은 방해 요소가 있다.

10. 나에게 발생하는 일들에 대해서 통제력이 거의 없다.

11. 내가 가지고 있는 모든 문제를 해결하는 것은 불가능하다.

12. 나는 종종 내 인생이 이리 저리 휘둘리고 있다고 생각한다.

주1) 1-4: 개인적 숙달감, 5-12: 지각된 제약 